\title{
The Dynamics of Adverse Incorporation in Global Production Networks: Poverty, Vulnerability and 'Slave Labour' in Brazil
}

Link to publication record in Manchester Research Explorer

Citation for published version (APA):

Phillips, N., \& Sakamoto, L. (2011). The Dynamics of Adverse Incorporation in Global Production Networks: Poverty, Vulnerability and 'Slave Labour' in Brazil. (Chronic Poverty Research Centre Working Papers series; No. 175).

\section{Citing this paper}

Please note that where the full-text provided on Manchester Research Explorer is the Author Accepted Manuscript or Proof version this may differ from the final Published version. If citing, it is advised that you check and use the publisher's definitive version.

\section{General rights}

Copyright and moral rights for the publications made accessible in the Research Explorer are retained by the authors and/or other copyright owners and it is a condition of accessing publications that users recognise and abide by the legal requirements associated with these rights.

\section{Takedown policy}

If you believe that this document breaches copyright please refer to the University of Manchester's Takedown Procedures [http://man.ac.uk/04Y6Bo] or contact uml.scholarlycommunications@manchester.ac.uk providing relevant details, so we can investigate your claim.

\section{OPEN ACCESS}




\section{Working Paper}

Chronic Poverty

February 2011

No. 175

Research Centre

\section{The dynamics of adverse} incorporation in global

production networks: Poverty,

vulnerability and 'slave labour'

in Brazil

What is Chronic Poverty?

The distinguishing feature

of chronic poverty is

extended duration in

absolute poverty.

Therefore, chronically poor people always, or usually,

live below a poverty line,

which is normally defined in

terms of a money indicator

(e.g. consumption, income,

etc.), but could also be

defined in terms of wider or

subjective aspects of

deprivation.

This is different from the

transitorily poor, who move

in and out of poverty, or

only occasionally fall below

the poverty line.

www.chronicpoverty.org
Nicola Phillips

Leonardo Sakamoto

Politics/Political Economy Institute

University of Manchester

Oxford Road, Manchester

M13 9PL, UK

Repórter Brasil

Rua Coronel Firmo da Silva

282, São Paulo-SP

01255-040, Brazil 


\section{Vulnerable workers in global production networks: Case studies of forced and child labour in Brazil and India}

The papers in this series emerged from a research project conducted under the auspices of the 'Adverse Incorporation and Social Exclusion' theme within the Chronic Poverty Research Centre. Amongst other things, this theme is concerned with the politics of efforts to tackle structural forms of chronic poverty (See CPRC Working Paper 81 'Adverse incorporation, social exclusion and chronic poverty'). The work reflected in these papers seeks to bring questions of vulnerable workers and participation in global production networks to the centre of these debates. The four papers seek together to explore how chronic poverty creates vulnerability to severely exploitative labour relations within global production networks, and in turn how and under what circumstances participation in global production networks can act not to alleviate but rather to entrench chronic poverty and marginalisation. The detailed comparative work reveals the different forms these dynamics take in different contexts, but equally demonstrates how the most severe forms of labour exploitation (often labelled 'forced labour') need to be understood, contrary to frequent assumptions, as an outcome and underpinning of the 'normal functioning' of global production networks. The papers seek to draw out the implications of these connections for how chronic poverty needs to be understood and addressed.

\section{Abstract}

Participation in increasingly complex global production networks (GPNs) can generate new employment opportunities, new sources of income and better working conditions for vulnerable workers and poor households. Yet, for many, the pattern is one of 'adverse incorporation', characterised by highly precarious and exploitative forms of employment, and a perpetuation of chronic poverty and vulnerability. In this paper we seek empirically and theoretically to understand the dynamics of adverse incorporation in GPNs by exploring two questions. First, to what extent, in what ways and under what circumstances does chronic poverty foster patterns of adverse incorporation in GPNs for poor workers and producers? Secondly, to what extent, in what ways and under what circumstances can the workings of GPNs, and the terms on which poorer producers and workers are incorporated, be said to produce and reproduce chronic poverty? We focus here on the worst forms of adverse incorporation associated with 'forced labour', and pursue our investigation through an original study of what is usually called 'slave labour' in Brazil, focusing on the bovine cattle sector.

Keywords: adverse incorporation, poverty, 'slave labour', Brazil, bovine cattle sector, global production networks 


\section{Acknowledgements}

The authors gratefully acknowledge research funding from the Chronic Poverty Research Centre (CPRC) for the project with which this study is associated. The paper draws on an original research report co-authored by Sakamoto with Maurício Hashizume, of Repórter Brasil, and Xavier Plassat, of the Pastoral Land Commission (CPT). Gabriel Alberto Trevizan and Julierme Zero Lima Barboza produced the maps, and additional data research was provided by Carlos Juliano Barros, Maurício Monteiro Filho and Rodrigo Rocha. We are grateful for the valuable participation of all these collaborators. We also appreciate the exacting and extremely helpful comments on early drafts of this paper from Stephanie Barrientos, Sam Hickey and Andrew Shepherd, along with useful reactions from delegates at the CPRC's conference in September 2010.

Nicola Phillips is Professor of Political Economy and Director of the Political Economy Institute at the University of Manchester, UK. She is also an editor of the journal New Political Economy, and she currently holds a Major Research Fellowship from the Leverhulme Trust (2010-13). Her research focuses on the political economy of development, with specific current interests in labour in global production networks, unfree labour and human trafficking, and migration and development. Her most recent books are Development (with Anthony Payne, Polity, 2010), and, as editor, International Political Economy: Debating the Past, Present and Future (with Catherine Weaver, 2010), and Migration in the Global Political Economy (Lynne Rienner, 2011).

Email: Nicola.phillips@manchester.ac.uk

Leonardo Sakamoto is a journalist and Chairman of the NGO Repórter Brasil, and has a $\mathrm{PhD}$ in Political Science from the University of São Paulo. He is a member of the Brazilian National Commission for the Eradication of Slave Labour, coordinator of the Brazilian Business Pact for the Eradication of Slave Labour, and author of the Second Brazilian National Plan for the Eradication of Slave Labour. Sakamoto has received several national and international prizes in journalism and human rights, such as the Brazilian National Prize of Human Rights and the Freedom Awards.

Email: leosaka@hotmail.com

This document is an output from the Chronic Poverty Research Centre (CPRC) which is funded by UKaid from the UK Department for International Development (DFID) for the benefit of developing countries. The views expressed are not necessarily those of DFID. The CPRC gratefully acknowledges DFID's support. 


\section{Contents}

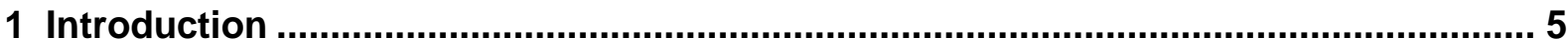

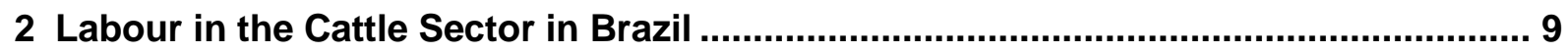

3 'Slave Labour' in the Cattle Sector.....................................................................12

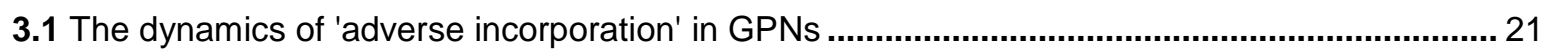

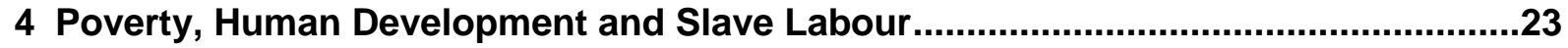

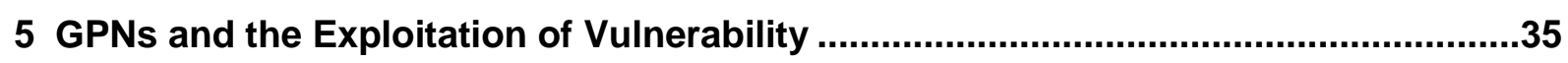

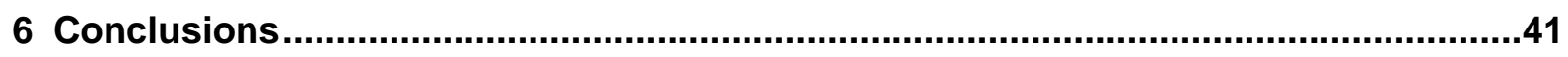

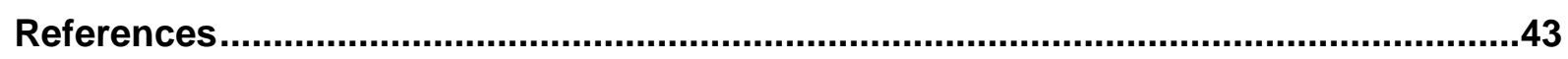

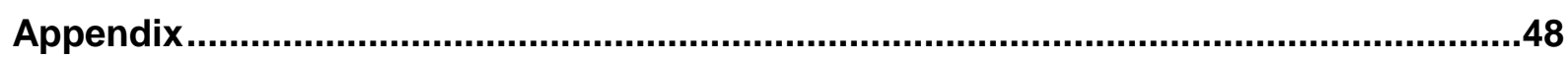




\section{Introduction}

Since the 1970s, the territorial and social geography of global production has been transformed by the forging of increasingly complex global production networks (GPNs), coordinated and dominated by global and local lead firms (Gereffi and Kaplinsky, 2001; Henderson et al., 2002; Gereffi et al., 2005; Gibbon et al., 2008; Bair, 2009). This process of restructuring has both required and reinforced a transformation of labour markets, alongside patterns of employment and work. The evidence indicates a substantial growth in precarious and insecure employment and in the numbers of highly vulnerable workers in the global economy, particularly as the use of low-skilled, low-paid, migrant and contract labour has become pivotal across production networks, often in informal conditions of work (Portes et al., 1989; Benería, 2001; Bauder, 2006; Cohen, 2006; Barrientos, 2008; Taylor, 2008; Phillips, 2011a,b). In this context, although long neglected in literatures on GPNs and cognate notions of global value chains (GVCs), the extent to which poorer producers and workers can and do gain from participation in GPNs is now beginning to command attention.

A huge body of classical and contemporary theory, associated particularly with the work of Joseph Schumpeter and Karl Marx, has established that capitalist development generates an intrinsic process of uneven growth and development. The workings and impact of contemporary GPNs reveal clearly these dynamics of unevenness, as selective economic upgrading is propelled for some parts of the economy and some groups of workers, and forms of what might be called 'downgrading' are pushed in and for others (Milberg, 2004; Kaplinsky, 2005; Ponte, 2008; Barrientos et al., 2010; Posthuma and Nathan, 2010). The differential impacts are often felt by groups of workers in the same sector or industry, as capitalist development produces and relies on a segmentation of the labour market (Peck, 1996; Bauder, 2006, 2011). Participation in expanding and increasingly complex GPNs can therefore generate new employment opportunities for vulnerable workers, providing new sources of income for poor households, higher wages, social protection and better working conditions. For many others, the pattern is one of what can be termed 'adverse incorporation' in GPNs, characterised by precarious, unprotected and exploitative forms of employment, with few possibilities for accumulation or longer-term socio-economic security.

The task, therefore, is to understand theoretically and empirically the relationship between the evolving workings of GPNs and the social outcomes experienced by labour in the global economy (Ponte, 2008; Barrientos et al., 2010). Our particular concern here is with the connections between particular patterns of integration into GPNs and social dynamics relating to poverty, deprivation and marginalisation. We address two key questions in this respect. First, to what extent, in what ways and under what circumstances does chronic poverty foster patterns of adverse incorporation in GPNs for poor workers and producers? Second, to what extent, in what ways and under what circumstances can the incorporation of poorer producers and workers into GPNs be said to produce or reproduce chronic poverty? In addressing these questions, we are able to expose to critical scrutiny the orthodox 
assumption that 'inclusion' in global economic activity (through employment) is the key to poverty reduction, and to illuminate the parallel dynamics of 'adverse incorporation' in GPNs which instead entrench poverty and vulnerability.

We pursue this investigation through a focus on the farther reaches of the spectrum of exploitation, namely, those associated with forms of 'forced' or 'unfree' labour. These labels refer to the kinds of labour relations which to the greatest extent deprive the worker of control over the sale of her key asset, namely, her labour, ${ }^{1}$ involving harsh and degrading forms of work, and in myriad ways curtailing her 'freedom' as a labourer and human being, in order to serve the accumulation strategies of the employer. In the context of GPNs, these take the predominant (but not exclusive) form of debt bondage - situations in which debts incurred to recruiters and/or employers are used to discipline the worker, 'bond' her to a particular employer. The key is our contention that forms of 'forced labour' do not, as is often assumed, represent a deviation from a norm in which inclusion in GPNs calls forth a process of 'social upgrading' alongside economic restructuring, nor an aberration in capitalist development. Rather, we conceptualise them as existing along a continuum of exploitative labour relations, responding to the same sets of market and social processes as other forms of exploitation which do not attract these labels. In other words, we take the ends of the continuum to represent the extreme manifestations of wider dynamics of adverse incorporation in GPNs.

The paper rests on a detailed empirical study of what is commonly termed 'slave labour' in Brazil - a country of particular importance in view of the salience of the problem and, moreover, the active government response to it since the mid-1990s. ${ }^{2}$ 'Slave labour' is defined in Brazilian law as '[r]educing someone to a condition analogous to slavery, whether by subjecting them to forced labour or exhaustive working hours, or by subjecting him or her to degrading working conditions or restricting their movement by any means, due to debts to the employer or its representative'. The key, unique component of this definition is its inclusion of 'degrading working conditions' - a much more encompassing criterion than that which is customarily used in definitions of 'forced labour'. The key government initiatives have been the development from 1995 onwards of a federal labour inspection system, the National Plan for the Eradication of Slavery in Brazil of 2003, and corresponding National Commission, and the establishment in 2003-04 of the 'Registry of employers that kept workers under conditions analogous to slavery', otherwise known as the 'dirty list' (lista suja). This functioned partly as a 'naming and shaming' mechanism, but also cut off flows of funds to these companies from government financial institutions. ${ }^{3}$ The National Pact for the

\footnotetext{
${ }^{1}$ This formulation is inspired by the discussion in Harriss-White (2005).

${ }^{2}$ Space prevents a discussion of why the term 'slave labour' is favoured in Brazil, or objections to it (Gomes, 2009). We use it here to acknowledge the distinctiveness of the Brazilian formulation, which is ubiquitously used in political and public debate in that country.

${ }^{3}$ The names of employers found to be in violation of national laws are included on the 'dirty list' following an administrative process in which employers are entitled to defend themselves. They are subsequently monitored for two years before they become eligible for removal from the list.
} 
Eradication of Slave Labour followed in 2005, inviting the commitment of firms and employers to the anti-slavery effort. ${ }^{4}$ In 2010 , the National Pact had over 130 full signatories that represented over 20 percent of Brazil's gross domestic product (GDP). These initiatives have meant that we now have an invaluable, albeit still limited and patchy, resource of hard data on a problem which occupies the darkest shadows of the global economy, and on which, inevitably, almost no substantial data exist.

The focus of our study is the bovine cattle sector. This sector is central to the contemporary Brazilian development model, and features high levels of integration into global networks of production and trade. It also accounts for over 60 percent of the production sites where the use of 'slave labour' has been identified by the mobile labour inspection units since 2003. Our study was conducted between late 2009 and mid-2010 across the states of the Eastern Amazon region (Pará, Tocantins, Maranhão and Mato Grosso), where the incidence of 'slave labour' is highest. The research involved, in the first instance, the collection and analysis of statistical information collated by both government and state agencies (the Ministry of Labour and Employment (MTE), Labour Prosecutors, Labour Justice, Federal Justice, Federal Police, Federal Road Police, and the Ministry of Agriculture and Livestock) and civil society organisations (notably the Pastoral Land Commission (CPT) and the non-governmental organisation (NGO) Repórter Brasil). These data were used to build detailed personal profiles of rural workers who had been identified as working in conditions analogous to slavery, as well as of the employers and enterprises for which they worked.

The second, qualitative dimension of the study involved interviews with rural workers freed from conditions analogous to slavery, cattle ranchers, representatives of large meat companies, and representatives of key supermarket chains. We identified rural workers and employers (landowners) for this purpose through the unemployment insurance databank of the MTE, alongside information about the operations conducted by the mobile labour inspection units which resulted in the identification and release of 'slave' workers. Predictably, the research process was long and difficult, given the difficulty of locating highly mobile workers who are among the most marginalised and 'invisible' members of the workforce, their reticence to speak, the challenges of interviewing people who have either no or limited literacy, and the reluctance of employers and other participants in the value chain to speak openly about these matters. Ultimately, two landowners and three workers were interviewed for the study, along with representatives of two global supermarkets and one meat company. These interviews thus provided valuable qualitative substance for analysis

\footnotetext{
${ }^{4}$ These initiatives have not uniformly been received as positive; notably, the National Farming Confederation filed a Direct Unconstitutionality Lawsuit at the Supreme Court in opposition.
} 
alongside the quantitative data. ${ }^{5}$ Finally, value chains were traced using existing data compiled by Repórter Brasil and new information collected during our field research.

The paper proceeds in five parts. The first provides background context about the nature of the cattle sector in Brazil, the production networks that structure it, and the problem of 'slave labour' within it. The second offers a theoretical framing, outlining the concept of 'adverse incorporation' in GPNs. The third and fourth analyse the dynamics of adverse incorporation in the specific context of the Brazilian cattle sector, integrating two areas of enquiry corresponding with the guiding questions outlined above, namely the links between chronic poverty, vulnerability and adverse incorporation; and the functioning of GPNs in general and the cattle value chain in particular. The conclusions pull the threads together.

\footnotetext{
${ }^{5}$ The cattle ranchers (landowners) were male, had been both reported by the mobile inspection group for use of slave labour and included at some point in the MTE's list of employers caught using slave labour, were part of domestic or international trade networks (through meat-packing companies or the export of live cattle), and owned ranches located in São Félix do Xingu, Marabá, Dom Eliseu or Rondon (Pará) and Açailândia or Bom Jesus das Selvas (Maranhão). The rural workers interviewed were also male; two of them were illiterate, one had education up to fourth grade incomplete, and the other had education up to eighth grade incomplete. One was in the 18 to 34 age bracket, two in the 25 to 34 bracket, and one in the 35 to 44 bracket. All had been liberated from conditions analogous to slavery by the mobile inspection group, had worked in these conditions for a period of between 2.69 and 4.80 months, and had worked for employers that conformed with the above profile. The three companies interviewed were multinationals - two foreign retailers and one Brazilian meat-packing company. All three are also members of the National Pact for the Eradication of Slave Labour and have adopted measures to block products from employers included in the 'dirty list'. The supermarkets export Brazilian meat production to foreign stores of the same group.
} 


\section{Labour in the cattle sector in Brazil}

Brazil is the world's largest exporter of meat, with around a fifth of the world market share, and in 2009 sales totalling US $\$ 4.11$ billion to over 100 countries. $^{6}$ The commercial bovine population is also the largest on the planet, growing by 17.4 percent between 2000 and 2008 to reach about 193 million head of cattle. ${ }^{7}$ The cattle sector represents the bellwether in the expansion of the agricultural frontier - that is, the evolving and geographically moving process through which original vegetation gives way to agricultural and extractive enterprises. The progressive displacement of cattle farming towards the Amazon region has occurred in the context of the vast expansion of other agri-business crops, notably sugar cane and soybean, in connection with the development strategy of making Brazil the world's leading producer of biofuels (see Biofuel Watch Center, 2009; Dauvergne and Neville, 2009; Meloni Nassar, 2009; Ubiraci Sennes and Narciso, 2009). Production of these crops has taken over vast swathes of the most valuable land, with the best infrastructure and closest to consumer centres, in the central and southern regions of the country, displacing cattle production increasingly towards the Amazon states. Since it is a predominantly extensive activity, furthermore, cattle farming needs cheap land, which is located mainly in agricultural frontier regions. Agricultural expansion in the Amazon has thus represented a mechanism of increasing the value and promoting the occupation of land that has no commercially viable use for other kinds of agricultural activity. At the same time productivity has been increasing as a result of expansion of the stock of cattle and the adoption of new farming techniques (Meloni Nassar, 2009: 62-63).

Meat-packing firms, including the giants JBS-Friboi, Bertin and Marfrig, have expanded and concentrated their activities in this region precisely in response to the lower production costs and the increase in the volume of production. In March 2007, the International Finance Corporation, connected to the World Bank, approved a loan of $\$ 90$ million to Bertin to expand its processing capacity of meat and leather in the Amazon. In turn, the presence of these firms has acted as a further spur to the expansion of cattle farming in the region, putting in place the necessary commercial and physical infrastructures. By 2008, the Amazon region was estimated to contain 74 million head of cattle, equivalent to 3.3 head of cattle per inhabitant and three times the national average. In 2007, the number of animals slaughtered in the Amazon region surpassed 10 million - 41 percent of the country's total (Friends of the Earth, 2008).

\footnotetext{
${ }^{6}$ Data from the Brazilian Association of Meat Exporting Industries (ABIEC). Available at: http://www.abiec.org.br/41 exportacao ano.asp. Accessed 1 December 2009.

${ }^{7}$ Data from the Brazilian Institute of Geography and Statistics (IBGE) and the Ministry of Development, Industry and Foreign Trade (MDIC). Available at: http://www.ibge.gov.br/home/estatistica/economia/ppm/2008/. Accessed 1 December 2009.
} 
This expansion of cattle farming occurs in frequent contravention of land, environmental and socio-legal requirements, and indeed is thereby enabled. An absence of clear control over land ownership and registration is prevalent across the Amazon states, complicating government supervision of land use, and facilitating cattle production on unregistered farms without compliance with environmental preservation rules. The links between the deforestation of the Amazon region and the expansion of cattle farming are indeed intimate, of long standing and, until fairly recently, socially sanctioned as a means of asserting land ownership. Of the 10 million new animals that were added to the total national stock between December 2003 and December 2006, fully 96 percent were grazing on land that had previously been Amazon forest. In other words, almost all the expansion of cattle farming in the Brazilian economy has taken place in the Amazon region, and has been facilitated by deforestation. The towns with the largest bovine populations are also the towns with the highest levels of deforestation. An example is São Félix do Xingu, in the state of Pará, which in 2008 had 1,812,870 head of cattle (27 per human inhabitant), ${ }^{8}$ and was the leading area for deforestation, having cleared $4,475.5 \mathrm{~km}^{2}$ of forest. ${ }^{9} \mathrm{~A}$ study conducted by the World Bank in 2003 noted the benefits to the agricultural economy from all these conditions, highlighting precarious land tenure, the ubiquitous 'grabbing' of public land for the purposes of its conversion into pasture and, of most concern to us here, the unlawful employment of labour (Margulis, 2003: 7).

This vast expansion of cattle farming in the Amazon has also been marked by the progressively closer integration of the sector into global networks of production and trade. On the one hand, this integration relates in the traditional sense to the growth of exports, consistent with the establishment of Brazilian agriculture overall in a dominant position in world markets. Advances in the treatment of disease and growing demand for protein in emerging economies, notably China, will lead to a further expansion of export production. On the other hand, the sector's strong integration into GPNs has occurred through a process in which lead firms have assumed a progressively dominant, coordinating position within the production system, consolidated through massive investments by the country's largest slaughter companies and the concentration of ownership in the hands of the large, nationalscale meat-packing industries, which are interested primarily in production for export. In 2007, five business groups led meat sales for the foreign market, accounting for 73.64 percent of total exports: JBS-Friboi, Bertin, Minerva, Marfrig and Independência Alimentos. JBS-Friboi, which acquired control of Bertin in 2009, is the largest meat-packing company in the world, producing both for the domestic market and export. Marfrig, similarly, bought or leased meat-packing plants from Margen and Mercosul and took control of a leather company (the Zenda Group), a provider to large automobile and aviation industries. By the

\footnotetext{
${ }^{8}$ Data from IBGE. Available at: http://www.ibge.gov.br/cidadesat/topwindow.htm?1. Accessed 1 December 2009.

${ }^{9}$ Data from the National Institute for Space Research. Available at:

http://www.obt.inpe.br/deter/bduc.php?id=4393\&LANGUAGE=PT. Accessed 1 December 2009.
} 
end of the 2000s, such firms were also pursuing expansive strategies of investing overseas in manufacturing and distribution facilities. The sector's integration into GPNs is thus not simply about exports in the traditional sense, but also about 'vertical integration and value aggregation strategies' (Meloni Nassar, 2009: 64).

It must be emphasised that no clear distinction exists between domestic and global production networks in this sector. Brazil has one of the largest domestic consumer markets in the world and, notwithstanding its position as the world's leading exporter of meat, 79 percent of total meat production was consumed internally in $2009 .{ }^{10}$ But the key point is that all the major Brazilian meat-processing companies produce simultaneously for domestic and international markets, and decisions about whether to sell in the domestic market or to export depend on conjunctural conditions of demand, price, prevailing trade conditions and the business terms that can be negotiated. The Brazilian market is embedded in the global market, and prices in the Brazilian stock market are linked to prices in other commodity markets that sell cattle, like that of the United States. Equally, many of the primary participants in the value chain, particularly supermarkets, are global brands which themselves structure GPNs in agriculture and agri-business. Thus, the notion that 'global' and 'domestic' production networks are distinct from one another is misleading, as are arguments about whether labour is utilised in correspondingly different forms. We will draw out the significance of this point later in the discussion. Here it needs simply to be clarified that the term GPNs refers to the production networks which structure the sector in question, oriented to both global and domestic markets.

\footnotetext{
${ }^{10}$ Data from ABIEC. Available at: http://www.abiec.com.br/3 pecuaria.asp. Accessed 1 December 2009.
} 


\section{3 'Slave labour' in the cattle sector}

Figure 1 details the main activities of the 164 properties that were on the official 'dirty list' of entities employing 'slave labour' published in December 2009; Figure 2 analyses the numbers of workers freed from conditions analogous to slavery according to economic activity. Tables 1 to 4 contribute additional detail, by sector, on allegations of slave labour, the number investigated, and the number of workers freed as a result. These additional data are important, as not all ranches identified as using slave labour in this period have been placed on the 'dirty list', either because an effective defence was mounted or because of ongoing delays in administrative and legal proceedings. Taken alongside the reports by mobile inspection groups, ${ }^{11}$ these data reveal that the incidence of slave labour is highest in industries associated with the production of commodities (where prices are set by world commodity markets), such as live cattle, soybean, cotton, sugar and coffee Other key products identified with slave labour are vegetal charcoal (raw material for the steel industry) and ethanol, which are not yet traded globally as commodities.

Figure 1: Properties cited on the 'dirty list', as at 22 December 2009, by area of activity

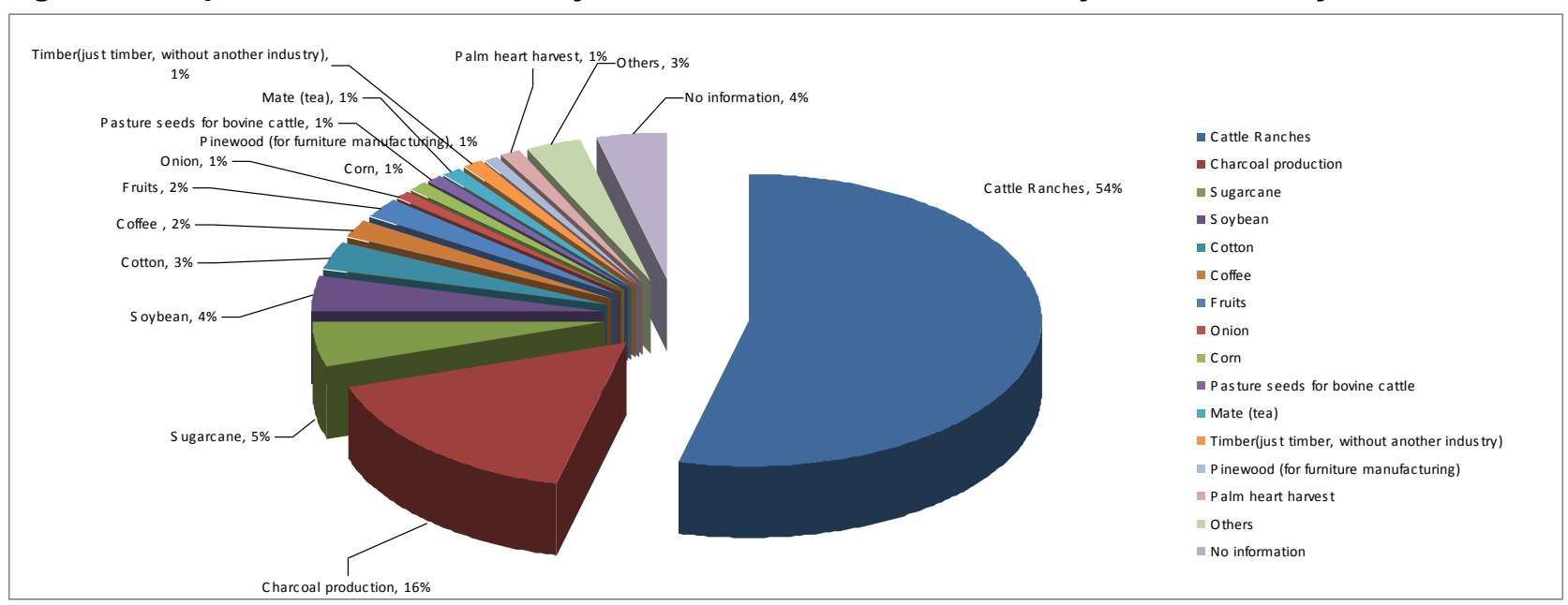

\footnotetext{
${ }^{11}$ Publicly available reports consulted at the headquarters of the MTE.
} 
Figure 2: Numbers of workers freed from properties cited on the 'dirty list', as at 22 December 2009 , by sector of activity

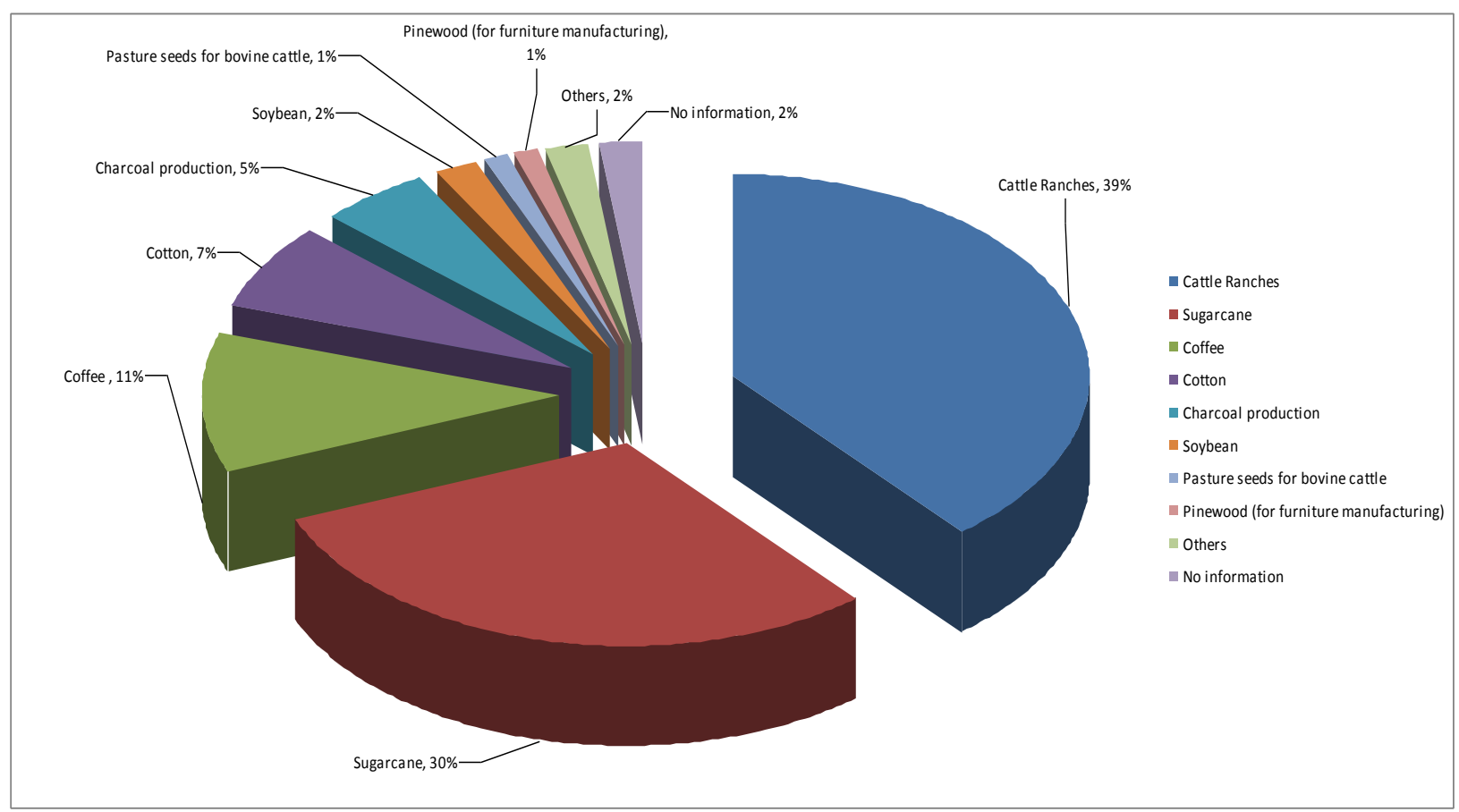

Table 1: Allegations, inspections and numbers of workers freed, by area of activity, 2003-09

\begin{tabular}{|l|l|l|l|l|l|l|}
\hline By activity 2003-09 & Cases reported & $\%$ & Cases inspected & $\%$ & Workers freed & $\%$ \\
\hline Deforestation & 89 & 5 & 60 & 5 & 1,744 & 5 \\
\hline Cattle & 1,053 & 59 & 557 & 50 & 9,572 & 30 \\
\hline Reforestation & 41 & 2 & 40 & 4 & 691 & 2 \\
\hline Extractive inds. & 24 & 1 & 14 & 1 & 471 & 1 \\
\hline Sugarcane & 54 & 3 & 49 & 4 & 9,129 & 29 \\
\hline Other crops & 193 & 11 & 148 & 13 & 5,426 & 17 \\
\hline Coal & 186 & 10 & 122 & 11 & 2,269 & 7 \\
\hline Others/ not informed & 141 & 8 & 117 & 11 & 2,469 & 8 \\
\hline Total & 1,781 & 100 & 1,107 & 100 & 31,771 & 100 \\
\hline
\end{tabular}

Source: CPT databank

Table 2: Allegations, inspections and numbers of workers freed, by area of activity, 2009

\begin{tabular}{|l|l|l|l|l|l|l|}
\hline By activity 2009 & Cases reported & $\%$ & Cases inspected & $\%$ & Workers freed & $\%$ \\
\hline Deforestation & 4 & 2 & 4 & 2 & 160 & 4 \\
\hline Cattle & 120 & 50 & 71 & 42 & 603 & 14 \\
\hline Reforestation & 12 & 5 & 11 & 7 & 105 & 2 \\
\hline Extractive inds. & 11 & 5 & 5 & 3 & 105 & 2 \\
\hline Sugarcane & 16 & 7 & 15 & 9 & 1,911 & 45 \\
\hline Other crops & 32 & 13 & 30 & 18 & 804 & 19 \\
\hline Coal & 27 & 11 & 18 & 11 & 300 & 7 \\
\hline $\begin{array}{l}\text { Others/not } \\
\text { informed }\end{array}$ & 18 & 8 & 15 & 9 & 295 & 7 \\
\hline Total & 240 & 100 & 169 & 100 & 4,283 & 100 \\
\hline
\end{tabular}

Source: CPT databank 
Table 3: Allegations, inspections and numbers of workers freed, by area of activity, 2008

\begin{tabular}{|l|l|l|l|l|l|l|}
\hline By activity 2008 & Cases reported & $\%$ & Cases inspected & $\%$ & Workers freed & $\%$ \\
\hline Deforestation & 7 & 3 & 7 & 3 & 83 & 2 \\
\hline Cattle & 134 & 48 & 85 & 39 & 1,029 & 20 \\
\hline Reforestation & 19 & 7 & 19 & 9 & 248 & 5 \\
\hline Extractive inds. & 5 & 2 & 5 & 2 & 49 & 1 \\
\hline Sugarcane & 19 & 7 & 19 & 9 & 2,553 & 48 \\
\hline Other crops & 35 & 13 & 30 & 14 & 731 & 14 \\
\hline Coal & 47 & 17 & 38 & 18 & 418 & 8 \\
\hline $\begin{array}{l}\text { Others/not } \\
\text { informed }\end{array}$ & 14 & 5 & 13 & 6 & 155 & 3 \\
\hline Total & 280 & 100 & 216 & 100 & 5,266 & 100 \\
\hline
\end{tabular}

Source: CPT databank

Table 4: Allegations, inspections and numbers of workers freed, by area of activity, 2007

\begin{tabular}{|l|l|l|l|l|l|l|}
\hline By activity 2007 & Cases reported & $\%$ & Cases inspected & $\%$ & Workers freed & $\%$ \\
\hline Deforestation & 12 & 5 & 5 & 3 & 55 & 1 \\
\hline Cattle & 157 & 59 & 81 & 53 & 1,430 & 24 \\
\hline Reforestation & 5 & 2 & 5 & 3 & 165 & 3 \\
\hline Extractive inds. & 2 & 1 & 0 & 0 & 0 & 0 \\
\hline Sugarcane & 9 & 3 & 7 & 5 & 3,060 & 51 \\
\hline Other crops & 18 & 7 & 11 & 7 & 476 & 8 \\
\hline Coal & 24 & 9 & 8 & 5 & 249 & 4 \\
\hline $\begin{array}{l}\text { Others/not } \\
\text { informed }\end{array}$ & 38 & 14 & 35 & 23 & 538 & 9 \\
\hline Total & 265 & 100 & 152 & 100 & 5,973 & 100 \\
\hline
\end{tabular}

Source: CPT databank

Cattle farming accounts for the largest number of properties, while the sugar cane sector accounts for the largest number of workers freed from these conditions in recent years. This is because of the much higher numbers of workers employed in sugar cane harvesting: cattle-related activities use groups of 30 people on average, while sugar cane harvesting might demand hundreds or thousands of workers at once. The MTE also increased its monitoring of the sugar cane sector in 2006 in response to the rise in national and international interest in ethanol production. The greater number of inspections led to an increase in the properties and workers identified as associated with slave labour. The much greater geographical inaccessibility of cattle ranches, concentrated as they are in the Amazon region, generates difficulties for both systems of labour inspection and accurate estimates of the incidence of slave labour. The trends established by the data are therefore to some extent shaped by the sectoral priorities of the MTE and the relative ease or difficulty of collecting data in the key sectors. 
Between 1995 and mid-2010, a total of 37,205 workers were freed from 'conditions analogous to slavery' in Brazil, overwhelmingly in rural areas and activities. ${ }^{12}$ This number clearly represents a very small fraction of the total Brazilian rural labour force of 17 million. Vastly more people work in undignified and exploitative conditions. 'Slave' labour therefore represents the peak of a pyramidal structure of exploitation, in which the number of workers increases as the degree of degradation and exploitation decreases, and the potential profit per worker is higher at the top of the pyramid. As its incidence is minor in the overall picture, the direct economy generated by the use of slave labour does not influence world commodity prices; rather, in the case of the production of commodities, the difference is made at the level of the rural producer. Nevertheless, profit results from all gradations of exploitation, and this range does affect world commodity prices and national and sectoral competitiveness.

The conditions defined as 'analogous to slavery' take a variety of forms across agricultural sectors. Workers in activities related to bovine cattle, vegetal charcoal and other extractive activities face highly degrading labour conditions, including beatings, psychological abuse and curtailment of freedom. The extreme inaccessibility of many Amazonian production sites is important, not only in isolating farms from the reach of the labour inspection system, but also in impeding the possibility for workers to move and leave. Conversely, workers in the sugar-alcohol industry, when they are not perpetual victims of debt bondage, are swallowed by a spiral of work paid by productivity (the metres of sugar cane they cut), often going to and exceeding the limits of their physical capacity. There were more than 20 deaths from exhaustion between 2004 and 2009 in the state of São Paulo. ${ }^{13}$

Having sketched the scale and sectoral profile of slave labour in the Brazilian economy, we can turn to its geographical and social profile. The data in Tables 5 to 8 provide detail about those workers who were released from conditions analogous to slavery and, under the Brazilian system, were consequently eligible for unemployment insurance for a period of three months. A total of 21,313 names were registered between January 2003 and October 2009. According to the CPT's databank, a total of 31,155 people were liberated from slave labour in the corresponding period. Therefore, the data from the MTE that we have used represent around 68 percent of the total of workers liberated in that period. Tables 5 and 6 indicate the place of birth of each worker; Tables 7 and 8 indicate their 'reference address', which is the address given by the worker for receiving government correspondence and other information. As a large proportion of rural workers are migrants, the reference address gives supplementary information which is not always captured by data on place of birth. The data are represented in map form in the Appendix.

\footnotetext{
${ }^{12}$ Data provided to the authors by the MTE's Labour Inspection Department.

${ }^{13}$ Deaths of workers in the sugar cane sectors are detailed at http://www.pastoraldomigrante.org.br/index.php?option=com content\&view=article\&id=44\%3Ahistorico-dos-cortadores-decana-mortos-no-setor-canavieiro-\&catid=47\%3Amemoria\&ltemid=38. Accessed 30 March 2010.
} 
Table 5: Leading places of birth of freed workers, by state (2003 to October 2009)

\begin{tabular}{|l|l|l|}
\hline State & Cases & \% \\
\hline Maranhão & 6,033 & 28.31 \\
\hline Pará & 1,677 & 7.87 \\
\hline Bahia & 1,637 & 7.68 \\
\hline Mato Grosso do Sul & 1,592 & 7.47 \\
\hline Piauí & 1,422 & 6.67 \\
\hline Minas Gerais & 1,360 & 6.38 \\
\hline Tocantins & 1,255 & 5.89 \\
\hline Pernambuco & 1,184 & 5.56 \\
\hline Alagoas & 926 & 4.34 \\
\hline Goiás & 912 & 4.28 \\
\hline
\end{tabular}

Source: MTE unemployment insurance database, as at October 2009

Table 6: Leading places of birth of freed workers, by town (2003 to October 2009)

\begin{tabular}{|l|l|l|}
\hline Town/state & Cases & $\%$ \\
\hline Amambaí/Mato Grosso do Sul & 464 & 2.18 \\
\hline Codó/Maranhão & 304 & 1.43 \\
\hline Caarapó/Mato Grosso do Sul & 265 & 1.24 \\
\hline Pastos Bons/Maranhão & 248 & 1.16 \\
\hline Imperatriz/Maranhão & 241 & 1.13 \\
\hline Barras/Piauí & 226 & 1.06 \\
\hline Santa Luzia/Maranhão & 182 & 0.85 \\
\hline Tacuru/Mato Grosso do Sul & 165 & 0.77 \\
\hline Colinas/Maranhão & 163 & 0.76 \\
\hline Caxias/Maranhão & 147 & 0.69
\end{tabular}

Source: MTE unemployment insurance database, as at October 2009

Table 7: Leading reference addresses, by state (2003 to October 2009)

\begin{tabular}{|l|l|l|}
\hline State & Cases & $\%$ \\
\hline Maranhão & 4,595 & 21.56 \\
\hline Pará & 3,728 & 17.49 \\
\hline Mato Grosso do Sul & 1,801 & 8.45 \\
\hline Tocantins & 1,608 & 7.54 \\
\hline Bahia & 1,339 & 6.28 \\
\hline Mato Grosso & 1,277 & 5.99 \\
\hline Minas Gerais & 1,162 & 5.45 \\
\hline Pernambuco & 1,020 & 4.79 \\
\hline Goiás & 1,002 & 4.70 \\
\hline Piauí & 996 & 4.67 \\
\hline
\end{tabular}

Source: MTE unemployment insurance database, as at October 2009 
Table 8: Leading reference addresses, by town (2003 to October 2009)

\begin{tabular}{|l|l|l|}
\hline Town/State & Cases & $\%$ \\
\hline Redenção/Pará & 409 & 1.92 \\
\hline Amambaí/Mato Grosso do Sul & 394 & 1.85 \\
\hline Naviraí/Mato Grosso do Sul & 278 & 1.30 \\
\hline Paragominas/Pará & 272 & 1.28 \\
\hline Caarapó/Mato Grosso do Sul & 256 & 1.20 \\
\hline Pastos Bons/Maranhão & 248 & 1.16 \\
\hline Ananás/Tocantins & 246 & 1.15 \\
\hline Santana do Araguaia/Pará & 242 & 1.14 \\
\hline Codó/Maranhão & 239 & 1.12 \\
\hline Itupiranga/Pará & 239 & 1.12 \\
\hline
\end{tabular}

Source: Tables 5-8: MTE unemployment insurance database, as at October 2009

The tables clearly reveal the correspondence between the agricultural frontier and the pattern of labour in the key sectors. The state of Maranhão, which leads the lists of both place of birth and reference address, is part of two regions of farming and extractive expansion - the Amazon to the west and Cerrado (savannah region) to the south - and is a major provider of labour to both, as well as to the sugar-alcohol industry in the mid-south region (Biofuels Watch Center, 2009). Among the 18 towns with 100 or more cases of slave labour among their natives, 12 are based in Maranhão. Similarly, Pará is one of the largest agricultural frontier regions, and Mato Grosso do Sul also stands out in view of the demand for labour in the sugar-alcohol and coal industries. In terms of cattle farming, the dirty list provides additional detail: in March 2010, of a total 161 ranches listed, seven were in the town of São Félix do Xingu (Pará) alone - five dedicated to cattle, and two to timber industries - from which 117 workers were liberated. That town has also had the most cases of slave labour in cattle farming, with 108 cases between January 2002 and June $2009 .{ }^{14}$

Many of the towns in the above tables (and in the more extended lists produced for the study) experience a significant out-migration of the working population during peak seasonal periods. The out-migration is to the mid-south and to other Amazon states such as Pará, which draws labour into the cattle sector from poor north-eastern regions in an east-west migration flow. According to our data, a 'pendular' pattern of migration appears to be the most common among workers who find themselves in conditions analogous to slavery - that is, a pattern of regular, usually seasonal migration, after which workers return to their home towns. There are two other patterns: non-migrant labour, and so-called peões de trecho ('road peons'), who leave their hometowns and move continuously in search of work. At the so-called 'peoneiro hotels', labour recruiters - known as gatos (cats) - buy the peões' debts and take them to ranches, either forcibly because they are being traded, or voluntarily as they believe they have found work which will allow them to honour commitments and make

\footnotetext{
${ }^{14}$ Data from surveys conducted by Xavier Plassat through the CPT.
} 
money. Although there are no reliable statistics on the size of this group, the general perception is that they represent the smaller share of the total population of 'slave' workers, and that the groups associated with pendular migration and non-migration are significantly larger.

The personal profile is overwhelmingly male and concentrated in the 18 to 34 age bracket (see Tables 9 and 10). Since the work in question demands considerable physical strength, employers and recruiters seek young men. Women are preponderant in activities such as harvesting and cleaning areas for plantations, and in ancillary activities such as cooking. There are also reports of women found in conditions of forced sexual labour in rural areas.

Table 9: Gender of liberated workers, accumulated from 2003

\begin{tabular}{|l|l|l|l|l|l|l|}
\hline Sex & $\begin{array}{l}\text { Number } \\
\text { April 2007 }\end{array}$ & $\begin{array}{l}\text { \% } \\
\text { April 2007 }\end{array}$ & $\begin{array}{l}\text { Number } \\
\text { March 2008 }\end{array}$ & $\begin{array}{l}\text { \% } \\
\text { March 2008 }\end{array}$ & $\begin{array}{l}\text { Number } \\
\text { December } \\
\mathbf{2 0 0 9}\end{array}$ & $\begin{array}{l}\text { December } \\
\mathbf{2 0 0 9}\end{array}$ \\
\hline Male & 9,307 & 95.34 & 14,236 & 95.7 & 20964 & 95.49 \\
\hline Female & 455 & 4.66 & 618 & 4.2 & 990 & 4.51 \\
\hline Total & $\mathbf{9 , 7 6 2}$ & $\mathbf{1 0 0 . 0 0}$ & $\mathbf{1 4 , 8 5 4}$ & $\mathbf{1 0 0 . 0 0}$ & $\mathbf{2 1 , 9 5 4}$ & $\mathbf{1 0 0 . 0 0}$ \\
\hline
\end{tabular}

Source: MTE unemployment insurance database, as at October 2009.

Table 10: Age at liberation, accumulated from 2003

\begin{tabular}{|l|l|l|l|l|l|l|}
\hline Age group & $\begin{array}{l}\text { Number } \\
\text { April 2007 }\end{array}$ & $\begin{array}{l}\text { \% } \\
\text { April 2007 }\end{array}$ & $\begin{array}{l}\text { Number } \\
\text { August } \\
\mathbf{2 0 0 8}\end{array}$ & $\begin{array}{l}\text { \% } \\
\text { August } \\
\mathbf{2 0 0 8}\end{array}$ & $\begin{array}{l}\text { Number } \\
\text { October } \\
\mathbf{2 0 0 9}\end{array}$ & $\begin{array}{l}\text { \% } \\
\text { October } \\
\mathbf{2 0 0 9}\end{array}$ \\
\hline Up to 17 & 363 & 3.72 & 231 & 1.33 & 621 & 2.91 \\
\hline $18-24$ & 2,764 & 28.31 & 4,868 & 28.11 & 6,424 & 30.14 \\
\hline $25-34$ & 3,100 & 31.76 & 6,023 & 34.78 & 6,960 & 32.66 \\
\hline $35-44$ & 1,940 & 19.87 & 3,431 & 19.81 & 4,181 & 19.62 \\
\hline $45-54$ & 1,189 & 12.18 & 2,029 & 11.72 & 2,315 & 10.86 \\
\hline 55 or over & 395 & 4.05 & 720 & 4.16 & 790 & 3.71 \\
\hline Unknown & 11 & 0.11 & 16 & 0.92 & 22 & 0.10 \\
\hline Total & $\mathbf{9 , 7 6 2}$ & $\mathbf{1 0 0 . 0 0}$ & $\mathbf{1 7 , 3 1 8}$ & $\mathbf{1 0 0 . 0 0}$ & $\mathbf{2 1 , 3 1 3}$ & $\mathbf{1 0 0 . 0 0}$ \\
\hline
\end{tabular}

Source: MTE unemployment insurance database, as at October 2009.

The final element of the profile relates to the time period during which a person works in conditions analogous to slavery (see Table 11). The pattern corresponds with the duration of a specific job - 3.46 months on average. It is in this sense, and significantly, most often a short-term relationship, which distinguishes slave labour in Brazil from the kinds of forced labour found in some other countries or sectors, where long-term and sometimes intergenerational relationships are more the norm. It is also possible that the average time spent working in such conditions will decrease over time as labour inspection units expand and become more effective. 
Table 11: Months worked before liberation (2002 to October 2009)

\begin{tabular}{|l|l|l|l|l|l|l|l|l|l|}
\hline Months & All & $\mathbf{2 0 0 9}$ & $\mathbf{2 0 0 8}$ & $\mathbf{2 0 0 7}$ & $\mathbf{2 0 0 6}$ & $\mathbf{2 0 0 5}$ & $\mathbf{2 0 0 4}$ & $\mathbf{2 0 0 3}$ & $\mathbf{2 0 0 2}$ \\
\hline Total & 21,954 & 2,809 & 4,504 & 5,540 & 3,106 & 3,140 & 2,008 & 809 & 38 \\
\hline Average & 3.46 & 3.47 & 4.80 & 2.69 & 2.91 & 3.32 & 3.51 & 3.63 & 4.47 \\
\hline
\end{tabular}

Source: MTE unemployment insurance databank, as at October 2009.

\subsection{The dynamics of 'adverse incorporation' in GPNs}

We are now in a position to turn to questions of how to understand these forms of labour relations, and specifically to enquire into their connections with patterns of chronic poverty and vulnerability. For this purpose we deploy here a perspective which rests on the notion of 'adverse incorporation', which stands as a challenge to influential orthodox understandings of poverty as strongly related to conditions of 'exclusion' - both as forms of 'social exclusion' and as exclusion from labour markets. The poor are deemed to be those who have failed to engage with global economic activity, and it is assumed that a deepening of globalisation will lift nearly (and eventually) all of the world's poor out of destitution (see Milanovic, 2003; Kaplinsky, 2005). This orthodox view is reflected in poverty reduction strategies at local and global levels, which rest on achieving the greater inclusion of poor producers and workers in global networks of production and trade, in order, as the World Bank (1990) put it, to enhance the 'productive use of the labour of the poor'.

These discourses of exclusion have attracted insightful objection from those who see poverty not as a 'residual' phenomenon, bound to be eliminated as the reach of global markets is extended, but rather as a 'relational' phenomenon, underpinned by particular kinds of power relations which are generated by global and local economic restructuring (see Bernstein, 1990; Wade, 2004; Kaplinsky, 2005; Glyn, 2006). The empirical record demonstrated clearly that inclusion through employment was not uniformly and always associated with a beneficial process of what might be called 'social upgrading' for workers, and indeed was at least as often associated with exploitative conditions of work, and a perpetuation of poverty and disadvantage. The notion of 'adverse incorporation' was therefore developed in order to conceptualise poverty not (only) as a condition of socio-economic exclusion, but as shaped by the terms on which different social groups are included and incorporated into global economic activity (Wood, 2000, 2003; Murray, 2001; Bracking, 2003; Hickey and du Toit, 2007; Ponte, 2008). It refers to those situations in which people have few or no prospects for accumulation through work or employment nor, consequently, for the alleviation of their chronic poverty and vulnerability. As summarised usefully by Geoff Wood (2000: 19), conditions of adverse incorporation arise when '[poor people] are obliged to manage [their] vulnerability through investing in and maintaining forms of social capital which produce desirable short-term, immediate outcomes and practical needs while postponing and putting at permanent risk more desirable forms of social capital which offer the strategic prospect of supporting needs and maintaining rights in the longer term' (emphasis in the original). 
In this respect, a useful perspective is found in the notion that destitution and poverty are associated respectively with a person's loss of control over assets and income, and specifically, in the case of the poor, over their key asset of labour (Harriss-White, 2005: 882). This loss of control can result both from a condition of exclusion and from the terms of inclusion. The dynamics of adverse incorporation can thus be understood as circular. The vulnerability associated with the loss of control that defines chronic poverty, alongside the overriding need to satisfy the short-term requirements of survival, can work to the advantage of capital in its creation and/or appropriation of a large pool of surplus, often informal and easily exploited labour. In turn, the adverse terms of incorporation into these labour markets (as insecure, informal and exploited labour) reinforce the loss of control which defines chronic poverty, perpetuating a circular dynamic which deprives workers of prospects for long-term accumulation and security. In these scenarios, inclusion in labour markets is not a means of lifting people out of poverty; rather, it is a mechanism by which they become trapped in it. Situations of forced or 'slave' labour represent the extreme manifestations of adverse incorporation, in which the loss of control is most pronounced: a person is either deprived entirely of control over the conditions in which s/he sells his or her labour in the marketplace (in those cases where extreme coercion is present), or else is obliged to sell it in conditions characterized by the worst forms of exploitation.

An understanding of the circular dynamics of adverse incorporation in GPNs thus requires, on the one hand, an exploration of how poverty makes workers vulnerable to precarious and exploitative employment and, on the other, an understanding of how patterns of employment and work within GPNs, and the power relations which underpin them, create and perpetuate the conditions and relations of chronic poverty. We address each of these questions in turn. 


\section{Poverty, human development and 'slave labour'}

The first step in tracing the connections between poverty and 'slave labour' consists in correlating the data presented above with indicators of human development. Tables 12, 13 and 14 compile data taken from the Human Development Index, organised according to the hierarchies of place of birth and reference address represented in the tables in the previous section. We add an indicator of the number of cattle in each town to show the importance of this industry in each case. The data are represented again in map form in the Appendix, allowing visual comparison with the patterns identified in earlier sections.

Table 12: Workers' place of birth - towns with highest occurrence of slave labour (2003 to October 2009)

\begin{tabular}{|c|c|c|c|c|c|c|c|}
\hline Town & State & $\begin{array}{l}\text { Population } \\
\text { (2009) }\end{array}$ & $\begin{array}{l}\text { Area } \\
\left(\mathrm{km}^{2}\right)\end{array}$ & $\begin{array}{l}\text { Number of } \\
\text { hospital beds } \\
\text { per } 1000 \\
\text { inhabitants } \\
\text { (2005) }\end{array}$ & $\begin{array}{l}\text { Students } \\
\text { enrolled in } \\
\text { basic school } \\
\text { per } 1000 \\
\text { inhabitants } \\
(2008)\end{array}$ & $\begin{array}{l}\text { Per capita } \\
\text { GDP (2007) } \\
\text { reais }\end{array}$ & $\begin{array}{l}\text { Head of cattle } \\
(2008)\end{array}$ \\
\hline $\begin{array}{l}\text { National } \\
\text { average }\end{array}$ & & & & 2.41 & 167.15 & 13,720 & $\begin{array}{l}202,287,191 \\
\text { (nat. total) }\end{array}$ \\
\hline Amambaí & MS & 34,986 & 4,202 & 4.52 & 185 & 9,132 & 392,520 \\
\hline Codó & MA & 113,937 & 4,365 & 1.36 & 221 & 3,160 & 45,879 \\
\hline Caarapó & MS & 23,696 & 2,090 & 1.98 & 184 & 13,114 & 140,428 \\
\hline Pastos Bons & MA & 18,306 & 1,620 & 0.87 & 176 & 2,115 & 17,865 \\
\hline Imperatriz & MA & 236,691 & 1,368 & 4.31 & 185 & 6,854 & 97,655 \\
\hline Barras & $\mathrm{Pl}$ & 44,913 & 1,722 & 1.87 & 221 & 2,698 & 18,269 \\
\hline Santa Luzia & MA & 71,455 & 6,133 & 1.54 & 243 & 2,922 & 190,925 \\
\hline Tacuru & MS & 9,554 & 1,785 & 0.21 & 227 & 7,966 & 178,056 \\
\hline Colinas & MA & 36,787 & 2,034 & 3.78 & 206 & 2,962 & 31,946 \\
\hline Caxias & MA & 148,072 & 5,224 & 1.14 & 216 & 5,282 & 43,592 \\
\hline
\end{tabular}

\begin{tabular}{|l|l|l|l|l|l|l|}
\hline Town & State & $\begin{array}{l}\text { Poverty } \\
\text { incidence, \% } \\
\text { of } \\
\text { population } \\
\mathbf{( 2 0 0 3 )}\end{array}$ & $\begin{array}{l}\text { Gini Index } \\
\mathbf{( 2 0 0 3 )}\end{array}$ & $\begin{array}{l}\text { Average monthly } \\
\text { salary, in units } \\
\text { equivalent to the } \\
\text { national minimum } \\
\text { wage (2007) }\end{array}$ & $\begin{array}{l}\text { Adult illiteracy } \\
\text { rate (\%) (2000) }\end{array}$ & $\begin{array}{l}\text { Child mortality } \\
\text { (deaths per } \\
\mathbf{1 0 0 0 )}(\mathbf{2 0 0 5 )}\end{array}$ \\
\hline National average & & $\mathbf{3 6 . 5}$ & $\mathbf{0 . 5 8}$ & $\mathbf{3 . 4}$ & $\mathbf{2 4 . 7 6}$ & $\mathbf{2 5 . 8}$ \\
\hline Amambaí & MS & 35.84 & 0.45 & 1.7 & 28.36 & 48.5 \\
\hline Codó & MA & 59.37 & 0.41 & 1.6 & 49.74 & 26.2 \\
\hline Caarapó & MS & 45.7 & 0.43 & 2.2 & 28.31 & 31.2 \\
\hline Pastos Bons & MA & 50.71 & 0.39 & 1.2 & 40.51 & 13.9 \\
\hline Imperatriz & MA & 55.28 & 0.46 & 1.8 & 27.59 & 20.5 \\
\hline Barras & PI & 54.03 & 0.41 & 1.3 & 50.09 & 17.5 \\
\hline Santa Luzia & MA & 55.66 & 0.38 & 1.9 & 52.92 & 23 \\
\hline Tacuru & MS & 41.12 & 0.42 & 2.4 & 34.47 & 48.3 \\
\hline Colinas & MA & 55.3 & 0.4 & 1.4 & 50.4 & 8.5 \\
\hline Caxias & MA & 58.44 & 0.43 & 1.5 & 43.74 & 27.8 \\
\hline
\end{tabular}

Notes: MA: Maranhão; MS: Mato Grosso do Sul; PI: Piauí.

Source: Data from the Brazilian Institute of Geography and Statistics (IBGE); Datasus; Ministry of Health's Mortality Information System and Live Births Informational System; Ferreira and Leite (2009). 
Table 13: Reference address provided by workers - towns with highest occurrence of slave labour (2003 to October 2009)

\begin{tabular}{|c|c|c|c|c|c|c|c|}
\hline Town & State & $\begin{array}{l}\text { Population } \\
\text { (2009) }\end{array}$ & $\begin{array}{l}\text { Area } \\
\left(\mathbf{k m}^{2}\right)\end{array}$ & $\begin{array}{l}\text { Number of } \\
\text { hospital beds } \\
\text { per } 1000 \\
\text { inhabitants } \\
(2005)\end{array}$ & $\begin{array}{l}\text { Students } \\
\text { enrolled in } \\
\text { basic school } \\
\text { per } 1000 \\
\text { inhabitants } \\
\text { (2008) }\end{array}$ & $\begin{array}{l}\text { Per } \\
\text { capita } \\
\text { GDP } \\
(2007) \\
\text { reais }\end{array}$ & $\begin{array}{l}\text { Head of cattle } \\
\text { (2008) }\end{array}$ \\
\hline National average & & & & 2.41 & 167.15 & 13,720 & $\begin{array}{l}202,287,191 \\
\text { (natl total) }\end{array}$ \\
\hline Redenção & PA & 67,064 & 3,824 & 2.88 & 232 & 8,224 & 161,725 \\
\hline Amambaí & MS & 34,986 & 4,202 & 4.52 & 185 & 9,132 & 392,520 \\
\hline Naviraí & MS & 45,627 & 3,194 & 2.78 & 168 & 12,269 & 261,025 \\
\hline Paragominas & PA & 97,350 & 19,331 & 1.50 & 231 & 7,493 & 418,976 \\
\hline Caarapó & MS & 23,696 & 2,090 & 1.98 & 184 & 13,114 & 140,428 \\
\hline Pastos Bons & MA & 18,306 & 1,620 & 0.87 & 176 & 2,115 & 17,865 \\
\hline Ananás & TO & 9,514 & 1,587 & 2.52 & 241 & 5,442 & 82,000 \\
\hline Santana do Araguaia & PA & 55,033 & 11,591 & 1.56 & 122 & 5,166 & 485,859 \\
\hline Codo & MA & 113,937 & 4,365 & 1.36 & 221 & 3,160 & 45,879 \\
\hline Itupiranga & PA & 41,541 & 7,880 & 1.23 & 261 & 3,744 & 330,700 \\
\hline
\end{tabular}

\begin{tabular}{|l|l|l|l|l|l|l|}
\hline Town & State & $\begin{array}{l}\text { Poverty } \\
\text { incidence } \\
\mathbf{( 2 0 0 3 )}\end{array}$ & $\begin{array}{l}\text { Gini Index } \\
\mathbf{( 2 0 0 3 )}\end{array}$ & $\begin{array}{l}\text { Average } \\
\text { monthly } \\
\text { salary, in } \\
\text { units } \\
\text { equivalent to } \\
\text { the national } \\
\text { minimum } \\
\text { wage (2007) }\end{array}$ & $\begin{array}{l}\text { Adult } \\
\text { illiteracy rate } \\
\text { (\%) (2000) }\end{array}$ & $\begin{array}{l}\text { Child } \\
\text { mortality } \\
\text { (deaths per } \\
\mathbf{1 0 0 0 )}(\mathbf{2 0 0 5 )}\end{array}$ \\
\hline National average & & $\mathbf{3 6 . 5}$ & $\mathbf{0 . 5 8}$ & $\mathbf{3 . 4}$ & $\mathbf{2 4 . 7 6}$ & $\mathbf{2 5 . 8}$ \\
\hline Redenção & PA & 38.54 & 0.4 & 2 & 29.02 & 24.4 \\
\hline Amambaí & MS & 35.84 & 0.45 & 1.7 & 28.36 & 48.5 \\
\hline Naviraí & MS & 41.58 & 0.45 & 2.7 & 24.85 & 23.3 \\
\hline Paragominas & PA & 39.1 & 0.41 & 1.8 & 36.46 & 23 \\
\hline Caarapó & MS & 45.7 & 0.43 & 2.2 & 28.31 & 31.2 \\
\hline Pastos Bons & MA & 50.71 & 0.39 & 1.2 & 40.51 & 13.9 \\
\hline Ananás & TO & 52.93 & 0.43 & 1.4 & 36.22 & 20.8 \\
\hline Santana do Araguaia & PA & 37.56 & 0.38 & 2.5 & 36.35 & 30.8 \\
\hline Codó & MA & 59.37 & 0.41 & 1.6 & 49.74 & 26.2 \\
\hline Itupiranga & PA & 45.43 & 0.37 & 1.8 & 48.94 & 32.4 \\
\hline
\end{tabular}

Source: MTE unemployment insurance database, as at October 2009. 
Table 14: Towns with highest incidence of slave labour (2002 to June 2009)

\begin{tabular}{|c|c|c|c|c|c|c|c|}
\hline Town & State & $\begin{array}{l}\text { Population } \\
(2009)\end{array}$ & $\begin{array}{l}\text { Area } \\
\left(\mathbf{k m}^{2}\right)\end{array}$ & $\begin{array}{l}\text { Number of } \\
\text { hospital beds } \\
\text { per } 1000 \\
\text { inhabitants } \\
(2005)\end{array}$ & $\begin{array}{l}\text { Students } \\
\text { enrolled in } \\
\text { basic school } \\
\text { per } 1000 \\
\text { inhabitants } \\
\text { (2008) }\end{array}$ & \begin{tabular}{|l} 
Per \\
capita \\
GDP \\
$(2007)$ \\
reais \\
\end{tabular} & $\begin{array}{l}\text { Head of cattle } \\
\text { (2008) }\end{array}$ \\
\hline National average & & & & 2.41 & 167.15 & 13,720 & $\begin{array}{l}202,287,191 \\
\text { (natl total) }\end{array}$ \\
\hline São Félix do Xingu & PA & 67,208 & 84,212 & 1.19 & 175 & 5,836 & $1,812,870$ \\
\hline Marabá & PA & 203,049 & 15,092 & 0.98 & 228 & 15,857 & 478,100 \\
\hline Dom Eliseu & $\mathrm{PA}$ & 39,088 & 5,268 & 3.15 & 250 & 5,088 & 134,457 \\
\hline Goianésia do Pará & PA & 29,164 & 7,021 & 1.99 & 247 & 4,694 & 187,380 \\
\hline Açailândia & MA & 101,130 & 5,806 & 1.36 & 218 & 18,569 & 450,152 \\
\hline Rondon do Pará & PA & 47,772 & 8,247 & 3.16 & 175 & 4,944 & 372,146 \\
\hline Itupiranga & PA & 41,541 & 7,880 & 1.23 & 261 & 3,744 & 330,700 \\
\hline Pacajá & PA & 41,953 & 11,832 & 0.67 & 223 & 3,535 & 370,333 \\
\hline Ananás & TO & 9,514 & 1,587 & 2.52 & 241 & 5,442 & 82,000 \\
\hline Paragominas & $\mathrm{PA}$ & 97,350 & 19,331 & 1.50 & 231 & 7,493 & 418,976 \\
\hline
\end{tabular}

\begin{tabular}{|l|l|l|l|l|l|l|}
\hline Town & State & $\begin{array}{l}\text { Poverty } \\
\text { incidence } \\
\mathbf{( 2 0 0 3 )}\end{array}$ & $\begin{array}{l}\text { Gini } \\
\text { Index } \\
\mathbf{( 2 0 0 3 )}\end{array}$ & $\begin{array}{l}\text { Average } \\
\text { monthly } \\
\text { salary, in } \\
\text { units } \\
\text { equivalent to } \\
\text { the national } \\
\text { minimum } \\
\text { wage (2007) }\end{array}$ & $\begin{array}{l}\text { Adult } \\
\text { illiteracy } \\
\text { rate (\%) } \\
\mathbf{( 2 0 0 0 )}\end{array}$ & $\begin{array}{l}\text { Child mortality (deaths } \\
\text { per 1000) (2005) }\end{array}$ \\
\hline National average & & $\mathbf{3 6 . 5}$ & $\mathbf{0 . 5 8}$ & $\mathbf{3 . 4}$ & $\mathbf{2 4 . 7 6}$ & $\mathbf{2 5 . 8}$ \\
\hline São Félix do Xingu & PA & 36.45 & 0.42 & 1.9 & 39.62 & 35.1 \\
\hline Marabá & PA & 42.73 & 0.41 & 2.4 & 31.58 & 23.9 \\
\hline Dom Eliseu & PA & 43.99 & 0.38 & 1.6 & 41.83 & 22.7 \\
\hline Goianésia do Pará & PA & 46.16 & 0.38 & 1.8 & 43.97 & 34.5 \\
\hline Açailândia & MA & 58.66 & 0.41 & 1.9 & 35.76 & 18.1 \\
\hline Rondon do Para & PA & 40.16 & 0.43 & 1.7 & 35.65 & 33.7 \\
\hline Itupiranga & PA & 45.43 & 0.37 & 1.8 & 48.94 & 32.4 \\
\hline Pacajá & PA & 40.22 & 0.4 & 1.7 & 43.89 & 33 \\
\hline Ananás & TO & 52.93 & 0.43 & 1.4 & 36.22 & 20.8 \\
\hline Paragominas & PA & 39.1 & 0.41 & 1.8 & 36.46 & 23 \\
\hline
\end{tabular}

Source: MTE unemployment insurance database, as at October 2009.

The first remark to make concerns the basic economic data relating to workers' place of birth and location of employment. As noted earlier, the vast majority of freed workers during this period came from the state of Maranhão, where annual per capita GDP is rarely over around 3,000 reais, roughly equivalent to US $\$ 1,700$ or just over a fifth of the national average. ${ }^{15}$ In none of the cities of birth is per capita GDP above or even near the national average. For the

\footnotetext{
${ }^{15}$ The dollar equivalents in this section were calculated roughly using exchange rates of mid-July 2010.
} 
towns with the highest incidence of 'liberation' cases, it is possible to infer a relationship between the occurrence of slavery and the total head of cattle.

Second, income poverty measures give a vivid statistical impression of the connections between economic deprivation and vulnerability to 'slave labour'. Income poverty here is defined by the Brazilian government's Institute of Applied Economic Research (IPEA) as referring to those families with per capita household income below half the minimum wage, and below one quarter in the case of extreme poverty. The tables show that in some instances income poverty figures are close to the national average of 36.5 percent, but in the vast majority substantially exceed it. In some cases, the figures indicate that well over half the total population lives in conditions of poverty and extreme poverty. Even in the towns not represented in the tables above, but which were included in our fuller dataset, poverty rates were always in excess of 30 percent. The data for average monthly wages also clearly show a pattern substantially below, and usually around 50 percent lower than, national averages for all the key locations. The monthly minimum wage in Brazil for 2007 was (from April onwards) 380 reais, roughly $\$ 215$, which makes the national average for that year around $\$ 731$ (3.4 monthly minimum wages). The average for the 10 towns listed is a monthly equivalent of 1.6 minimum wages - about $\$ 344$ or 47 percent of the national average monthly wage.

Third, the data relating to other human development indicators are more mixed. Most towns mentioned both as places of birth and as reference address have child mortality rates below the national average, except for some in Mato Grosso do Sul and Pará. North-eastern towns, whether the origin or destination of workers, display lower child mortality rates than in the North or Mid-west. The number of hospital beds and children in education are usually not far from the national average, and in many cases exceed this average. These patterns are primarily the result of the federal government's targeted social programmes over the 2000s, which increased the coverage of education and health systems. But the data represent a snapshot of the situation in the mid- to late 2000s, when these strategies had already yielded a clear impact, and do not take into account temporal issues relating to the situations of nowadult workers who are vulnerable to highly exploitative forms of employment.

The figures on literacy and educational attainment are illuminating in this respect. The tables above provide the overall data for adult illiteracy in the key towns of birth, reference and work, showing figures that are often substantially above national averages, in some cases exceeding 50 percent of the total population. Tables 15 and 16 provide supplementary information on the educational level of workers released from conditions analogous to slavery between 2003 and 2009. In October 2009, 40.14 percent of the workers included in the database since 2003 were classified as illiterate, along with 30.85 per cent of those included between January 2008 and October 2009. The category of 'illiterate' accounts for the highest proportion of workers in both tables, followed by the category of workers with only basic primary education. The figures accumulated from 2003 to October 2009 reveal that 
fully 68.13 percent of freed workers were illiterate or had no more than four years of schooling.

Table 15: Educational level, accumulated from 2003

\begin{tabular}{|c|c|c|c|c|c|c|}
\hline $\begin{array}{l}\text { Educational } \\
\text { level }\end{array}$ & $\begin{array}{l}\text { Number of } \\
\text { workers } \\
\text { April } 2007\end{array}$ & $\begin{array}{l}\% \\
\text { April } 2007\end{array}$ & $\begin{array}{l}\text { Number of } \\
\text { workers } \\
\text { August } 2008\end{array}$ & $\begin{array}{l}\% \\
\text { August } 2008\end{array}$ & $\begin{array}{l}\text { Number of } \\
\text { workers } \\
\text { October } \\
2009\end{array}$ & $\begin{array}{l}\% \\
\text { October } \\
2009\end{array}$ \\
\hline Illiterate & 4,355 & 44.61 & 7,378 & 42.6 & 8,554 & 40.14 \\
\hline $\begin{array}{l}\text { 4th grade } \\
\text { incomplete }\end{array}$ & 2,991 & 30.64 & 4,881 & 28.2 & 5,966 & 27.99 \\
\hline $\begin{array}{l}\text { 4th grade } \\
\text { complete }\end{array}$ & 619 & 6.34 & 1,251 & 7.2 & 1,609 & 7.55 \\
\hline $\begin{array}{l}\text { 8th grade } \\
\text { incomplete }\end{array}$ & 971 & 9.95 & 2,217 & 12.8 & 2,918 & 13.69 \\
\hline $\begin{array}{l}\text { 8th grade } \\
\text { complete }\end{array}$ & 186 & 1.91 & 504 & 2.9 & 644 & 3.02 \\
\hline $\begin{array}{l}\text { High school } \\
\text { incomplete }\end{array}$ & 104 & 1.07 & 258 & 1.5 & 383 & 1.80 \\
\hline $\begin{array}{l}\text { High school } \\
\text { incomplete }\end{array}$ & 84 & 0.86 & 263 & 1.5 & 371 & 1.74 \\
\hline $\begin{array}{l}\text { Incomplete } \\
\text { higher education }\end{array}$ & 1 & 0.01 & 4 & 0.01 & 11 & 0.05 \\
\hline $\begin{array}{l}\text { Complete higher } \\
\text { education }\end{array}$ & 0 & 0.00 & 0 & 0.0 & 1 & 0.00 \\
\hline Unknown & 451 & 4.62 & 562 & 3.2 & 856 & 4.02 \\
\hline Total & 9,762 & 100.00 & 1,7318 & 100.00 & 2,1313 & 100.00 \\
\hline
\end{tabular}

Source: MTE unemployment insurance database, as at October 2009.

Table 16: Educational level, January 2008-October 2009

\begin{tabular}{|l|l|l|}
\hline Educational level & Quantity & $\%$ \\
\hline Illiterate & 2,054 & 30.85 \\
\hline 4th grade incomplete & 1,848 & 27.75 \\
\hline 4th grade complete & 599 & 9.00 \\
\hline 8th grade incomplete & 1,206 & 18.11 \\
\hline 8th grade complete & 250 & 3.75 \\
\hline High school incomplete & 188 & 2.82 \\
\hline High school incomplete & 182 & 2.73 \\
\hline Incomplete higher education & 8 & 0.12 \\
\hline Complete higher education & 1 & 0.02 \\
\hline Unknown & 323 & 4.85 \\
\hline Total & $\mathbf{6 , 6 5 9}$ & $\mathbf{1 0 0 . 0 0}$ \\
\hline
\end{tabular}

Source: MTE unemployment insurance database, as at October 2009. 
These data thus reveal the manner in which low levels of education contribute to the vulnerability of workers to adverse incorporation in GPNs, including those forms associated with 'slave labour'. A further dimension of this vulnerability relates to the connections between workers' past experiences of child labour, where minors are engaged in work instead of education, and subsequent patterns of 'slave labour' as adults. There presently exist no significant quantitative data determining child labour as an entry point to slave labour - inevitably, given the nature of the issue - but qualitative research, including that conducted for this study, indicates a strong connection (see Pyl, 2010).

Our interviews with rural workers released from conditions analogous to slavery provided illustrations of how and why adult workers were deprived of education as children. One worker (age 44) did not attend school, receiving only lessons from a relative, and still cannot write his own name. He began working in the fields with his father, in order to help the family, when he was a boy, although he does not remember his age at the time. Another worker (age 27) reported that he began working at the age of 14 because his family was very poor, initially in the production of vegetables, then in a car repair shop. He left school for the first time at seven years old, because there were no schools near the place to which the family had moved for work. His schooling finished in the third grade of elementary school although he returned to education in adult life. The cases of these workers indicate that conditions of economic poverty have been pivotal in pushing children out of education and into work. The case of the second worker is also particularly instructive as he was deprived of education by the lack of schools and school transport in rural areas. The third worker interviewed was not a child worker but, having reached only the eighth grade of elementary school by the age of 18, illustrates the low levels of education which correlate strongly with vulnerability to extreme exploitation.

Interestingly, however, the data reveal a shift over time. As indicated in Table 14, between 2003 and April 2007 the number of illiterate people plus those with up to four years of schooling represented 75.25 percent of the total of workers freed. The percentage falls to 70.8 percent in the figures accumulated to August 2008, and to 68.13 percent to October 2009. For the period between 2008 and October 2009, the figure is 58.6 percent. We are therefore seeing a steady decrease in the proportion of freed workers with no or only basic education or, in other words, an improvement in average levels of schooling among these workers. These early data appear to indicate a direct impact of education and social policy, specifically the universalisation of basic school provision and government social programmes such as the Programme to Eradicate Child Labour (PETI) and the Family Grant programme (Bolsa Família). Both of these programmes involve cash transfers to poor families on the condition of verification that their children attend school. The new and future entrants to the labour market, who in the cattle sector are overwhelmingly young men, will thus have had more years of formal education and will have been beneficiaries of social policies intended to keep children in education. 
Nonetheless, this improvement in the educational profile of vulnerable workers does not seem to correlate with an equally marked decrease in the incidence of 'slave labour' and other exploitative forms of work. Given the inevitable absence of reliable data on the precise scale of 'slave labour', we cannot cross-reference statistics with any accuracy. The question of whether government income transfer and social programmes have reduced the population's vulnerability to highly exploitative labour relations therefore remains an open one, and of course one which depends for its answer on a certain time lag. But impressionistic evidence suggests that the picture is not unambiguously positive. It is fair to say that issues of poverty and slave labour have been tightly connected in government strategies. In December 2005, for instance, the Ministry of Social Development and Hunger Alleviation (MDS) and the MTE signed a technical cooperation agreement on the social resettlement of workers freed from conditions analogous to slavery, and a system of information exchange was later established in order to cross-reference data about liberated workers and beneficiaries of the Family Grant. Even so, there have been problems in universalising the unemployment benefit to workers. The MDS relates these to the difficulty of locating people freed from slavery, since the address provided by workers is not always either real or accurate, or else changes rapidly as people move on for work. ${ }^{16}$

Other issues also complicate the link between government income transfer programmes and reducing the vulnerability of poor workers. The Family Grant programme reached 12.4 million households in 2009 , paying 12.4 billion reais (around $\$ 6.86$ billion) in benefits to families with monthly per capita income under an equivalent of $\$ 77.48$, and living in situations classified as poverty or extreme poverty. The difficulty is that the profile of some of the workers who are vulnerable to adverse incorporation as 'slave labour' is not consistent with measurements of extreme poverty; rather, they are drawn from strata that would be classified as 'poor', 'working poor' or even 'lower middle class', according to official numerical measurements of income-based poverty. Crucially, employers and recruiters in agricultural sectors, including cattle farming, do not seek chronically starving or malnourished people - the poorest of the poor - since they need individuals with the appropriate physical condition for extremely demanding forms of manual work. For this reason, the workers in question are more likely to slip through, or be only partially captured by, the nets of government social protection policies, forming the population of working poor engaged in highly precarious patterns of employment, often involving migration, and vulnerable to exploitation and abuse in this context.

Our interviews with rural workers, corroborated by the analysis of government labour inspection reports, indicate that economic necessity is central to decisions to migrate for work. Significantly, in instances where workers find themselves in conditions analogous to slavery, it was often the case that they had made the same pendular migration before and

\footnotetext{
${ }^{16}$ Information provided to the authors from MTE and the MDS.
} 
earned money that they deemed sufficient to justify their return. In other words, the risk of highly exploitative employment was traded against the possibility of adequate remuneration, which would have been higher than the wages earned by non-migrant workers or those without the physical condition to be viable workers. Under conditions of chronic need, any job is seen as better than no job, any money advanced means relief (notwithstanding its translation into debt), and any promise of good money means 'unrefusable' good luck. There is no such thing as a bad job, except 'when the guy does not keep his word, he doesn't pay', as one worker put it. The workers routinely reject the idea of leaving the job prematurely:

We don't have the right to do so. Because the job must be finished, right? If I take a job to do, l'll finish it. (Difran)

No, can't do that. It's got to be finished. We'd need the money, right? If you don't finish, they don't pay you. (Adão)

His [the employer's] worst violence was saying to me that he didn't owe me nothing and that if I wanted my rights to be respected, I should go after him in the Labour Courts. And that he wouldn't pay me. [...] The violence was when I said I could no longer work, then I saw that ... I opened my eyes, I saw that it was not possible anymore, and then he changed his ways with me. (Leonildo)

Adão's recognition of his working conditions jar with these comments, indicating the vulnerability to exploitation that arises from chronic need:

In the mud during the day and in the mud during the night. A shack, by the pit. Bad work, in the mud. The shack, when it rained, we'd untie the hammock to wait for the rain to stop. It was like that. That's why it was no good. Then they said: you guys can't work like that. Cattle are being treated better than you. The feds told us that. The water was, like, from a pit. They even said, dirty water. Water to drink and to bathe came from the same pit.

Particularly in the sugar cane sector, many workers also indicate a conscious decision to tolerate such dehumanising conditions as these, often over years, in view of the possibility of earning three times the minimum wage during the harvesting season. In the cattle sector, as indicated earlier, the forms that slave labour takes are rather different, more often involving the 'classic' traits of non-payment of wages and curtailment of freedom, alongside the elements of hardship and deprivation that result from inadequate food, shelter, hygiene and sanitation.

The key point is thus that income poverty measures provide a poor guide to the extent of vulnerability among the labour force. It is instead important to recognise the 'multidimensionality' of poverty, which encompasses such issues as education, literacy and access to social infrastructure. The lack or incomplete coverage of institutions and public policies that might guarantee quality of life for those workers increases their dependence on income, and such matters as the emphasis on basic education, rather than skills and vocational training, entrench the vulnerability of unskilled manual workers to the kinds of 
exploitative incorporation that we have been discussing here. Therefore, even though many workers liberated from slavery may be earning higher wages than those considered extremely poor, and have higher overall income levels, they have very limited education and live in places deprived of social infrastructure and employment opportunities. Consequently they are vulnerable to continuous and repeated cycles of exploitation. 


\section{$5 \quad$ GPNs and the exploitation of vulnerability}

We have established that Brazilian agriculture, including the cattle sector, is strongly integrated into and shaped by GPNs, characterised as it is by the heightened involvement of foreign capital in domestic production structures, the concentration of ownership in the huge firms selling in national and international markets, and energetic domestic and overseas investment strategies on the part of Brazilian lead firms. The question then arises of how and why workers' participation in these GPNs often takes the form of 'adverse incorporation', including the extreme forms discussed here. We now identify a series of mechanisms by which this occurs.

We have noted that the expansion of GPNs in the cattle sector, and their increasing domination by powerful lead firms, have been intimately linked to the shifting agricultural frontier, specifically to the increased colonisation of the Amazon region by cattle farming. In one respect, this process of colonisation has occurred through practices of 'land grabbing', facilitated by poor systems of land registration and the geographical inaccessibility of huge parts of the Amazon region. In some cases this has involved land historically owned by existing populations, and their consequent displacement - a process akin to the notion of 'accumulation by dispossession' revived of late by David Harvey (2003) and based on Marx's notions of primitive accumulation. The displaced occupiers are then obliged to make themselves available as workers to the new 'owners' of the land, or else to insert themselves into labour markets and seek employment elsewhere. Whether framed in Marxist terms or otherwise, this process of dispossession through 'land grab' is a key mechanism of capitalist accumulation, in this case through the expansion of cattle farming in the Amazon which is pivotal to the prevailing Brazilian development model. Even without dispossession or displacement, the progressive colonisation of land in the Amazon by large corporate interests acts to foreclose access to land for the poor in the region, again driving them into labour markets as part of the pool of available labour, and making them vulnerable to exploitation for the reasons noted in previous sections of the paper. The extension of the agricultural frontier and expansion of livestock production are also strongly associated with the appropriation of 'slave labour' for the clearing of forest and cleaning of pasture, as well as all other activities associated with cattle ranching. That is, the physical act of deforestation (chopping down trees and clearing land) is often performed by workers operating under conditions analogous to slavery. All other forms of cattle ranching activity are equally marked by the appreciable incidence of 'slave labour', as part of the continuum of exploitative labour relations and harsh working conditions which characterises the sector.

The key point is revealed by an analysis of the dirty list, as well as by a mapping of supply chains conducted by Repórter Brasil between 2004 and 2007: ${ }^{17}$ enterprises employing labour

\footnotetext{
${ }^{17}$ See http://www.reporterbrasil.com.br/pacto/conteudo/view/9l. Accessed 1 December 2009.
} 
under conditions analogous to slavery tend not to be small farms producing for local markets (within the same town or region), but rather larger-scale agricultural enterprises producing for national and international markets. Trade in cattle-related products is driven by large meatpacking companies of domestic and foreign capital that export to markets in the United States, the European Union, South America, the Middle East, Southern Asia and Africa. Equally, the main meat-packing companies which purchase and slaughter cattle raised by ranchers included in the 'dirty list' in 2007 were global players. In 2007, analysis of the patterns of trade in the relevant GPNs revealed that the countries connected to the productive chain of slave labour included Germany, Angola, Saudi Arabia, Bolivia, Canada, China, South Korea, Egypt, the United Arab Emirates, Spain, the United States, France, Holland, Hong Kong, Italy, Lebanon, Portugal, Britain and Russia. Empirically, therefore, there is a strong connection between the dynamics of accumulation within GPNs, dominated by domestic or foreign lead firms, and exploitative patterns of incorporation for many workers, including those subjected to conditions analogous to slavery.

The mechanisms by which this connection emerges relate to the intense competition between the many 'factions of capital' participating in the value chain, particularly where those chains are most complex and within which lead firms are able to impose the weightiest commercial pressures on price, quality and the logistics of production. As in all GPNs, our study of the Brazilian cattle industry has demonstrated the manner in which these pressures, and associated risk, are pushed up the value chain to less powerful producers and more vulnerable workers occupying particular geographical and social locations in the global economy. This process equates to the 'low-road' to upgrading, where economic competitiveness is pursued by worsening labour conditions (Barrientos et al., 2010). In other words, the 'normal functioning' of GPNs (Ponte, 2008) generates competition between factions of capital, in order to enhance accumulation for the dominant factions of capital and increase profit along the value chain. This competition is then refracted through the relation between capital and labour and, in many cases, manifested in exploitative labour relations.

Along the cattle value chain, participants within each node of production (or faction of capital) note the pressures that emanate from other parts of the value chain for ever-increasing 'competitiveness', which in this context is premised overwhelmingly on cost reduction. In the cattle industry, the main point of reference for the producers (landowners) is the meatpacking firms, which they identify as engaging in purchasing practices they deem to be dishonest and 'exploitative'. Landowner A, a producer cited on the dirty list, noted in our interview that:

In fact, what happens is monopoly [by meat-packing companies]. They don't really give our product the value it has. They pay little. [...] they end up making a lot of money on the backs of producers. ... There are always companies that shut down and leave debts to producers. Then we don't know if they are not paying on purpose or if they really paid a high price for the producer's meat and now they can't sell it for a price that is enough to remain in business. 
There are always companies that pay a bit more. We say that when they are too helpful, then there's something up ... The best meat-packing company is the one that steals less from you. They help you [by paying more] two or three times, and then they take something ten times. Almost all of them play that game. I can't say all, because I haven't sold to all of them, but it's always like that. All producers, all colleagues tell the same story. 'Well, the guy exploited me. I sent it to such and such a buyer and they exploited me'.

The issue of exports is more related to meat-packing companies. We have no direct connection to the export of the product. [...] We'd sure be interested, not only me, but everyone here. We think about that. One of the ideas we think about at the Association is to set up our own meat-packing company with meat with [quality] seal and a guarantee that all employees are well treated, that the environmental issue is right.

The series of pressures experienced by the producers is in this sense passed up the chain to the workers themselves, including in the use of non-contractual forms of employment and 'slave labour', as in the case of the landowners interviewed for this study. The same landowner complained about the tax burden imposed on the sector and the weight of labour and environmental legislation, even admitting one of the classic forms of fraud in the industry, namely, the illegal 'outsourcing' of documents to regularise meat that would be refused in the market on social and environmental grounds. If a ranch is included in the 'dirty list' (or indicted for environmental crimes), its production would be boycotted by meatpacking companies and retail chains that were signatories to the National Pact for the Eradication of Slave Labour or other 'ethical production' initiatives. But these restrictions are circumvented through complex networks between producers, such that those included on the dirty list can still sell in the market by 'laundering' the output through 'clean' third parties. In the view of landowner $A$ :

The government forces you, the laws force you to work illegally. You are forced to work illegally. You pay your taxes on time - and we pay absurd taxes - and still have to work illegally. [...] I want to sell cattle. You have to issue a GTA [Registration of Livestock Transit]. You have to issue GTAs through third parties, because if you cannot issue them directly to meat-packing companies, you have to do it to third parties, and then they will issue it to companies, see? ... You cannot trade it, you won't sell, then you have to sell it to third parties. Selling directly to meat-packing companies is complicated. You end up dirty.

The representatives of both the meat-packing company and the two supermarket networks interviewed concurred inasmuch as they saw rural producers as the most pressured link in the meat chain. A small number of cattle ranchers have tens of thousands of cattle and huge areas of land at their disposal, and are thus powerful economic actors able to influence prices and business conditions. But the vast majority of rural producers are smaller and depend on the purchasing practices of buyers. They are nevertheless the main target of criticism by public authorities, civil society and the press regarding labour, social and 
environmental issues in the meat production chain. They also earn less than the processing industry and the exporters. As the representative of supermarket chain A put it:

I think producers have the lowest profit. And also it is highly divided between retail and the cattle industry [...] We have the pressure of competition, which creates more regulation in the sector. Within the retail sector, it is almost impossible to make price cartels in today's Brazilian market. Because there is pressure, when you speak of meat, there is pressure by informal dealers, who can sell for prices that are even lower than those of formal ones. And competition does not come only from supermarkets, but also from butchers, small grocery stores [...] And l'd say that such pressure falls more on producers than on retail itself. Because retail also has a lot of bargaining power [...] we make a lot of pressure for the meat company to follow several basic production criteria in order to put meat on the shelves. And that industry will certainly pressure producers.

Interestingly, in our interviews, the representatives of both the meat-packing company and the supermarkets defended rural producers, pointing out their information deficit in relation to social, labour and environmental issues. The representative of the meat-packing company instead criticised the retail sector, contending that the problem is precisely that supermarkets leave the implementation of their social responsibility policies to rural producers:

Producers suffer the highest pressure in the chain. There's nothing they can do, right? ...Retailers are hypocritical sometimes. Retail's 'carbon food tree' issue falls totally on providers, you see, so they have to work more closely with the providers. They do that green-washing over and over again. They have to work more closely, bring producers, bring cattle ranchers, talk to them, say what the advantages are. Because within five years it will get really hard to enter the retail market. If you don't have A, B and C, no deal.

Here, as in all GPNs, intense competition thus acts to push pressure and responsibility up the chain, from retailers to meat-packing firms, and from meat-packing firms to producers. But the last link is not the producer, but rather the labour s/he uses, and frequently it is poor workers who absorb the pressures thus transmitted, including in the most exploitative and abusive kinds of labour relations that we have identified here. Recall from earlier that the incidence of slave labour is too minor directly to influence world commodity prices; rather the difference is made at the level of the rural producer, who is thus enabled to maintain participation in intensely competitive markets. Yet the base of the pyramid of exploitation is enormous, consisting of a huge labour force of poor and vulnerable workers. The terms of inclusion for many such workers are clearly 'adverse', inasmuch as they are marked by precarious, unprotected work characterised by myriad 'unfreedoms' and abuse. They are exploitative inasmuch as they are premised on the extraction of value in an extreme version of unequal exchange.

These kinds of exploitation in turn act in a variety of ways to sustain the patterns of chronic poverty in the key regions of labour supply and among workers themselves. The money that would have been made in wages and other benefits to workers under non-exploitative labour 
relations flows instead to rural producers and/or into and down the value chain to which the ranch is connected. Volatile conditions of business and trade in GPNs - especially endemic in GPNs connected with commodities - act to reinforce the extreme precariousness of employment and livelihoods, which in turn reinforce the conditions of chronic need which inform the strategies and decisions of workers. Furthermore, conditions analogous to slavery entail a wide range of physical and health dangers for workers, which include, in agricultural activities, the lack of protection from the effects of pesticides and inadequate safety equipment when operating heavy machinery, alongside the effects of poor sanitation and nutrition, lack of shelter, physical abuse and punishing manual work (Prado and Figueira, 2009). Physical damage and incapacity in turn act to create and reinforce poverty (HarrissWhite, 2006: 1244) as workers lose the physical attributes necessary for viability in the labour market, and workers and their families thus lose the means of ensuring their biological and social reproduction.

The final issue to note is that, at the same time, GPNs have been the major spawning beds of responses to the problems of 'unethical' production and trade. There have been important attempts to increase the requirements on corporate actors in areas of social responsibility, and these demands have become incorporated into the business model of many of the largest corporate actors, including in Brazil where the key mechanism has been the 'dirty list'. In recent years, retail networks such as Carrefour, Wal-Mart and Pão de Açucar have established various trade restrictions on meat-packing groups connected to producers cited in the list, including Bertin and Minerva. Bertin incurred losses of up to 50 million reais as a result of boycotts. In July 2009, Nike announced that it would not buy cattle leather originating from the Amazon region until there was a 'reliable governance system' in place, and Wal-Mart requested the right to use independent auditing systems in order to resume business in the region. Many of these initiatives related to deforestation rather than specifically to slave labour, and few have been fully effective. Nevertheless they indicate increasing market pressure on the cattle sector (see Leitão, 2009). Yet retailers fall back on the consumer as the ultimate arbiter of ethical considerations associated with labour (and environmental) standards. In this sense, responsibility, or even blame, is passed once more down the value chain to the 'end user'. As the representative of one of the supermarket chains put it:

All productive chains end up in retail. We're talking a 60,000-item store, so how can I control 60,000 ? It's impossible. What we can do, what we must do is getting the chains that really have visible problems and work on those chains. [...] But consumers are what is most lacking. They must also demand. Because consumers, when they buy, they act politically. They reinforce a positive business or a negative business, depending on their choice. So, what good is there if I make a move on the cattle chain, with company X, if I depend on it? And if consumers want to buy only meat from that company? So if I cut a provider [from the 'dirty list' of slave labour] from my category, it would not hesitate to sell through other means and consumers would keep demanding. Maybe [consumers] would punish our business for not having the product and would not buy from it anymore. 


\section{Conclusions}

In Brazil, as across the world, forms of 'slave', 'forced' and otherwise highly exploitative labour have long existed: their emergence is not historically novel and not per se caused by the evolution of GPNs or the contemporary globalisation of the world economy. Yet the evolution of GPNs has in many contexts, and for huge numbers of workers, been associated with precarious and exploitative labour relations; equally, the incidence of 'slave labour' within GPNs has been appreciable and, apparently, deeply entrenched. We deployed here a notion of 'adverse incorporation' to understand theoretically and empirically why and how the terms of inclusion in GPNs are frequently associated with the reinforcement of poverty and vulnerability. We conceptualised the associated dynamics as circular in nature: on the one hand, conditions of poverty create vulnerability to precarious exploitative labour relations and 'slave labour'; on the other, these vulnerabilities are exploited within GPNs and the power relations which create them are reinforced.

Three conclusions emerge with particular force from our study. First, the study reinforces the challenge to orthodox views of 'inclusion' through employment as the route out of poverty for the world's poor workers, and indeed to those which see the worst forms of exploitation 'forced' or 'slave' labour - as bound thereby to be eradicated. The picture is empirically much more complex, and theoretically more challenging. The 'normal functioning' of GPNs is as much associated with the dynamics of 'adverse incorporation' as it is with a beneficial process of 'social upgrading' (Ponte, 2008; Barrientos et al., 2010). Moreover, we have emphasised that 'slave labour' cannot be viewed as an aberration or deviation from the normal functioning of capitalism in general and GPNs in particular, rejecting the tendency in many parts of academic and policy debates to imagine that a separation needs to be drawn between these practices and other kinds of 'normal' labour exploitation (see Lerche, 2007; Phillips and Mieres, 2010). Rather, we have conceptualised 'slave labour' as a complex phenomenon which is clearly associated with the normal functioning of GPNs, and responds to the same sets of market pressures and forces as different levels and kinds of exploitation in evidence along the value chain. It represents an extreme manifestation and form of adverse incorporation, but nonetheless is one which remains in evidence across the global economy.

The challenge to the orthodoxy of 'inclusion' as poverty reduction is reinforced by the profile of the vulnerable workers on whom this study has focused. We saw that the poorest of the poor remain excluded from the GPNs surrounding Brazilian agriculture, given the physical condition demanded of the workforce employed in punishing manual labour. Thus, the reach of GPNs often does not extend to the poorest and most vulnerable parts of the world's population, and thus the orthodox faith in 'inclusion' as the route to lifting people out of poverty appears clearly misdirected. 
Second, our study has highlighted the ways in which a statistical measurement of income is a poor guide to understanding poverty and vulnerability to 'adverse incorporation'. In the Brazilian case, as just noted, the profile of 'slave labour' does not correspond with patterns of extreme income poverty. Equally, work in conditions analogous to slavery can involve reasonable remuneration even while the kinds of work and human existence involved are degrading, dehumanising and grossly exploitative. The key is instead the extent of insecurity and instability of employment and income, which constrain the worker's possibilities for accumulation and the achievement of long-term security. Other indicators of human development impinge heavily on patterns of vulnerability: in this respect we noted particularly the role of illiteracy or low levels of education, and the lack of social infrastructure and services. Our study therefore suggests the need for further, detailed work on the question of who is vulnerable to adverse incorporation, and under what circumstances, rejecting a simplistic response of 'the poor'.

Finally, the question of 'under what circumstances' extends to the nature of GPNs themselves. Our discussion suggested that the level of competition tends to be most intense in those chains dominated and coordinated by powerful lead firms. But it suggests a challenge to the assumption in much GPN analysis that adverse incorporation is most strongly associated with 'buyer-driven' value chains dominated by 'Northern-based' actors (Ponte, 2008; see Gereffi 1994). The discussion here does indeed point to the importance of lead firms, buyers and giant retailers, but suggests that these are not necessarily 'Northernbased'. In our case, the lead firms are global actors, but produce simultaneously for the huge domestic market and for export, and are more likely to be Brazilian than 'Northern-based'. Furthermore, our study has challenged the distinction between 'global' and 'domestic' production networks, highlighting the ways in which these are strongly integrated.

This qualification resonates with parallel debates around the question of whether 'forced' or 'slave' labour is more likely to be found in production systems oriented to local or domestic markets, or in production systems oriented towards export activity and associated with GPNs. Clearly, these labour relations are found in both kinds of systems, and across a huge array of production activities, some integrated into international markets and others involving very localised activity. Our study suggests that the task is to understand the various forces and factors which facilitate the emergence and persistence of the worst forms of exploitation in different contexts. In GPNs we identified the key force as the intense competition between factions of capital, which, indeed, is precisely what GPNs evolved in order to foster. This combines in different settings with various forms of socio-economic, cultural and racial marginalisation, structures of impunity and corruption, limitations to the reach of regulatory systems like labour inspections, and the shortcomings of social and welfare policy. A full understanding of the worst forms of exploitation in the global economy thus requires attention to the 'normal functioning' of GPNs and the terms on which workers participate in them, as well as to the more particular realities of poverty, vulnerability and marginalisation among huge swathes of the global labour force. 


\section{References}

Bair, J. (Ed.) (2009). Frontiers of Commodity Chain Research. Stanford, CA: Stanford University Press.

Barrientos, S. (2008). 'Contract labour: the Achilles heel of corporate codes in commercial value chains'. Development and Change, 39 (6), 977-990.

Barrientos, S., Gereffi, G. and Rossi, A. (2010). 'Economic and social upgrading in global production networks: developing a framework for analysis'. Working Paper 2010/03, Capturing the Gains research network, University of Manchester.

Bauder, H. (2006). Labor Movement: How Migration Regulates Labor Markets. New York: Oxford University Press.

Bauder, H. (2011). 'The regulation of labour markets through migration'. In Phillips, N. (Ed.), Migration in the Global Political Economy. Boulder, CO: Lynne Rienner.

Benería, L. (2001). 'Shifting the risk: new employment patterns, informalization, and women's work'. International Journal of Politics, Culture and Society, 15 (1), 27-53.

Bernstein, H. (Ed.) (1990). The Food Question: Profits vs People. London: Earthscan.

Biofuel Watch Center (2009). Brazil of Biofuels: Sugarcane 2009 - Impacts of Crops on Land, Environment and Society. São Paulo: Repórter Brasil.

Bracking, S. (2003). 'The political economy of chronic poverty', CPRC Working Paper 23. Manchester, UK: Chronic Poverty Research Centre (CPRC).

Cohen, R. (2006). Migration and its Enemies: Global Capital, Migrant Labour and the Nation-State. London: Ashgate.

Dauvergne, M. and Neville, K.J. (2009). 'The changing North-South and South-South political economy of biofuels', Third World Quarterly, 30 (6), 1087-1102.

Ferreira, F.H.G. and Leite, P.G. (2009). 'Halving Brazil's poverty, 1983-2006'. In von Braun, J., Vargas Hill, R. and Pandya-Lorch, R. (Eds), The Poorest and the Hungry: Assessments, Analysis and Actions. Washington, DC: IFPRI, 355-365.

Friends of the Earth (2008). O reino do gado: uma nova fase na pecuarização da Amazônia brasileira. São Paulo: Friends of the Earth.

Gereffi, G. (1994). 'The organization of buyer-driven global commodity chains: how US retailers shape overseas production networks'. In Gereffi, G. and Korzeniewicz, M. (Eds), Commodity Chains and Global Capitalism. Westport, CT: Praeger, 95-122.

Gereffi, G., Humphrey, J. and Sturgeon, T. (2005). 'The governance of global value chains'. Review of International Political Economy, 12 (1), 78-104.

Gereffi, G. and Kaplinsky, R. (Eds) (2001). 'The Value of Value Chains: Spreading the Gains from Globalisation', IDS Bulletin (special issue), 32 (3).

Gibbon, P., Bair, J. and Ponte, S. (2008). 'Governing global value chains: an introduction'. Economy and Society, 37 (3), 315-338. 
Glyn, A. (2006). Capitalism Unleashed: Finance, Globalization, and Welfare. Oxford: Oxford University Press.

Gomes, A. de Castro (2009). 'Trabalho análogo a de escravo: construindo um problema', mimeo, Rio de Janeiro.

Harriss-White, B. (2005). 'Destitution and the poverty of its politics - with special reference to South Asia'. World Development, 33 (6), 881-891.

Harriss-White, B. (2006). 'Poverty and capitalism', Economic and Political Weekly, 1 April, 1241-1246.

Harvey, D. (2003). The New Imperialism. Oxford: Oxford University Press.

Henderson, J., Dicken, P., Hess, M., Coe, N. and Yeung, H.W-C. (2002). 'Global production networks and the analysis of economic development'. Review of International Political Economy, 9 (3), 436-464.

Hickey, S. and du Toit, A. (2007). 'Adverse incorporation, social exclusion and chronic poverty', CPRC Working Paper 81. Manchester, UK: Chronic Poverty Research Centre (CPRC), June.

Kaplinsky, R (2005). Globalization, Poverty and Inequality. Cambridge: Polity.

Leitão, M (2009). 'Carne com crime', O Globo, 23 July.

Lerche, J. (2007). 'A global alliance against forced labour? Unfree labour, neo-liberal globalization and the International Labour Organization', Journal of Agrarian Change, 7 (4), 425-452.

Margulis, S. (2003). Causes for Deforestation in the Brazilian Amazon. Brasília: World Bank.

Meloni Nassar, A. (2009). 'Brazil as an agricultural and agroenergy superpower', in Brainard, L. and Martinez-Diaz, L. (Eds), Brazil as an Economic Superpower? Understanding Brazil's Changing Role in the Global Economy. Washington, DC: Brookings Institution, 55-80.

Milanovic, B. (2003). 'The two faces of globalization: against globalization as we know it'. World Development, 31 (4), 667-683.

Milberg, W. (Ed.) (2004). Labor and the Globalization of Production. Basingstoke: Palgrave Macmillan.

Murray, C. (2001). 'Livelihoods research: some conceptual and methodological issues'. CPRC Working Paper 5. Manchester, UK: Chronic Poverty Research Centre (CPRC).

Peck, J. (1996). Workplace: The Social Regulation of Labor Markets. New York: Guilford.

Phillips, N. (Ed.) (2011a). Migration in the Global Political Economy. Boulder, CO: Lynne Rienner, forthcoming.

Phillips, N. (2011b) 'Informality, global production networks and the dynamics of "adverse incorporation"', Global Networks, forthcoming.

Phillips, N. and Mieres, F. (2010). 'Fielding the wrong ball? A critique of global policy approaches to "forced labour"'. Paper prepared for the Chronic Poverty Research Centre conference, University of Manchester, 8-10 September. 
Ponte, S. (2008). 'Developing a "vertical" dimension to chronic poverty research: some lessons from global value chain analysis'. CPRC Working Paper 111. Manchester, UK: Chronic Poverty Research Centre (CPRC), June.

Portes, A., Castells, M. and Benton, L.A. (Eds) (1989). The Informal Economy: Studies in Advanced and Less Developed Countries. Baltimore, MD: Johns Hopkins University Press.

Posthuma, A. and Nathan, D. (Eds) (2010). Labour in Global Production Networks in India. New Delhi: Oxford University Press.

Prado, A.A. and Figueira, R.R. (2009). 'Trabalho escravo por dívida e condições degradantes na area da saúde', mimeo, Federal University of Rio de Janeiro.

Pyl, B. (2010). 'There's no excuse not to eliminate child labour, says the ILO', Repórter Brasil, 11 June. Available at: http://www.reporterbrasil.org.br/exibe.php?id=1756.

Taylor, M. (2008). 'Power, conflict and the production of the global economy'. In Taylor, M. (Ed.), Global Economy Contested: Power and Conflict across the International Division of Labour. London: Routledge.

Ubiraci Sennes, R. and Narciso, T. (2009). 'Brazil as an international energy player'. In Brainard, L. and Martinez-Diaz, L. (Eds), Brazil as an Economic Superpower? Understanding Brazil's Changing Role in the Global Economy. Washington, DC: Brookings Institution, 17-54.

Wade, R. (2004). 'Is globalization reducing poverty and inequality?'. World Development, 32 (4), 567589.

Wood, G. (2000). 'Concepts and themes: landscaping social development'. Social Development SCOPE Papers 9, London: Department for International Development (DfID).

Wood, G. (2003). Staying secure, staying poor: the "Faustian bargain"'. World Development, 31 (3), 455-471.

World Bank (1990). World Development Report 1990: Poverty. New York: Oxford University Press. 


\section{Appendix}

Appendix 1: Slave worker profile

Cases of slave labour found by inspections by town (2003-2009)

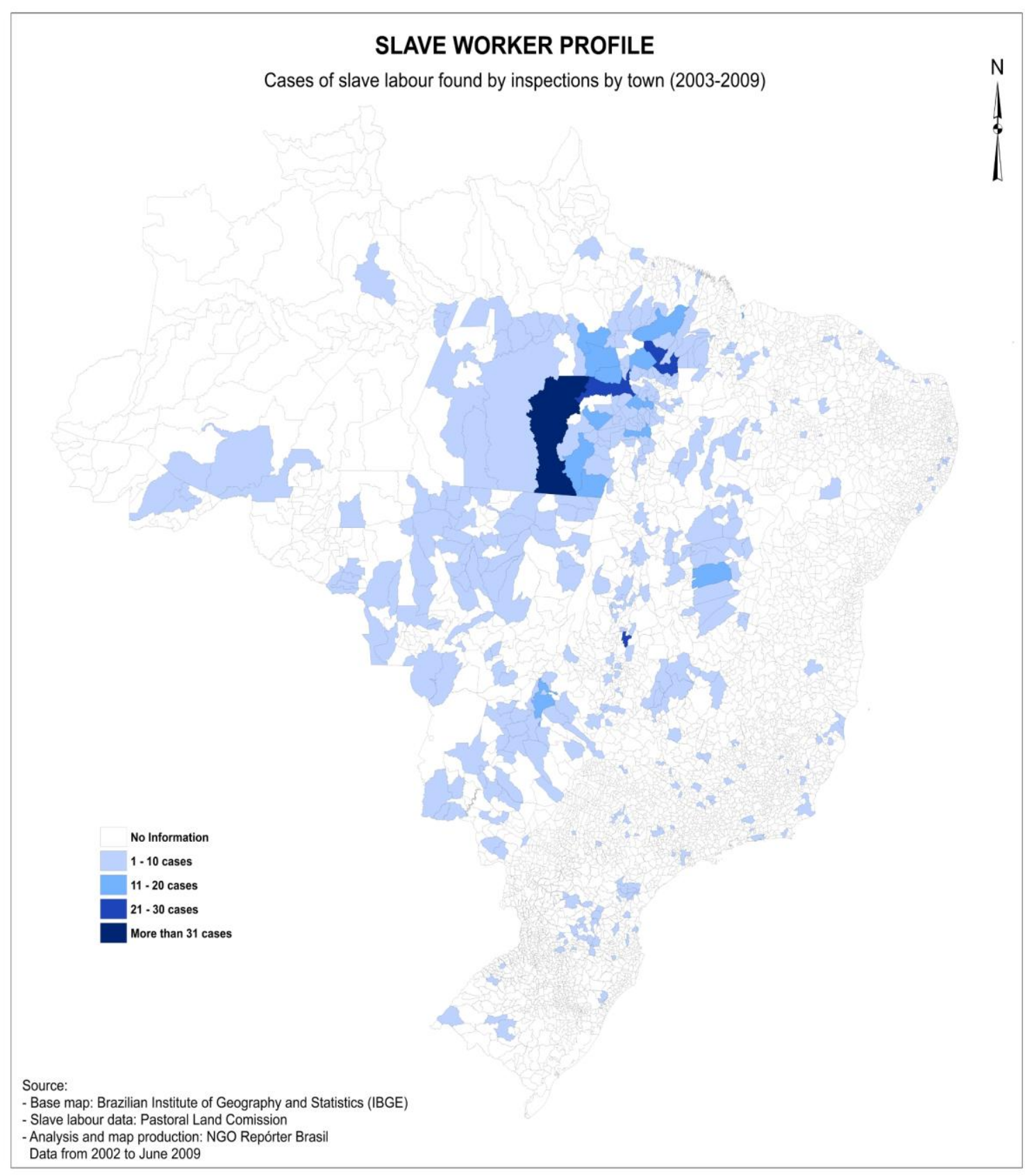




\section{Appendix 2: Slave worker profile}

Workers' place of birth by town (2003-2009)

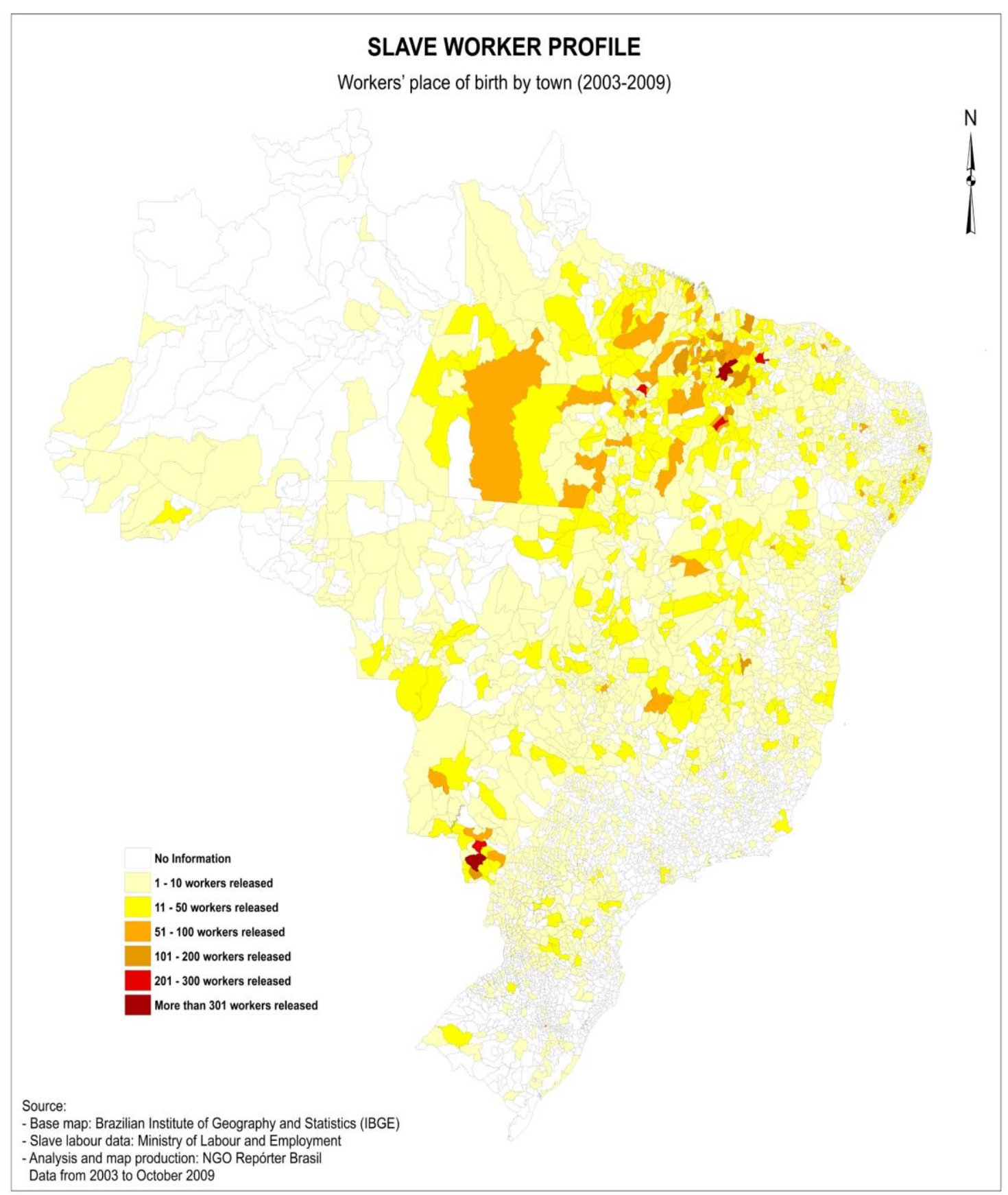




\section{Appendix 3: Slave worker profile}

Reference address provided by workers by town (2003-2009)

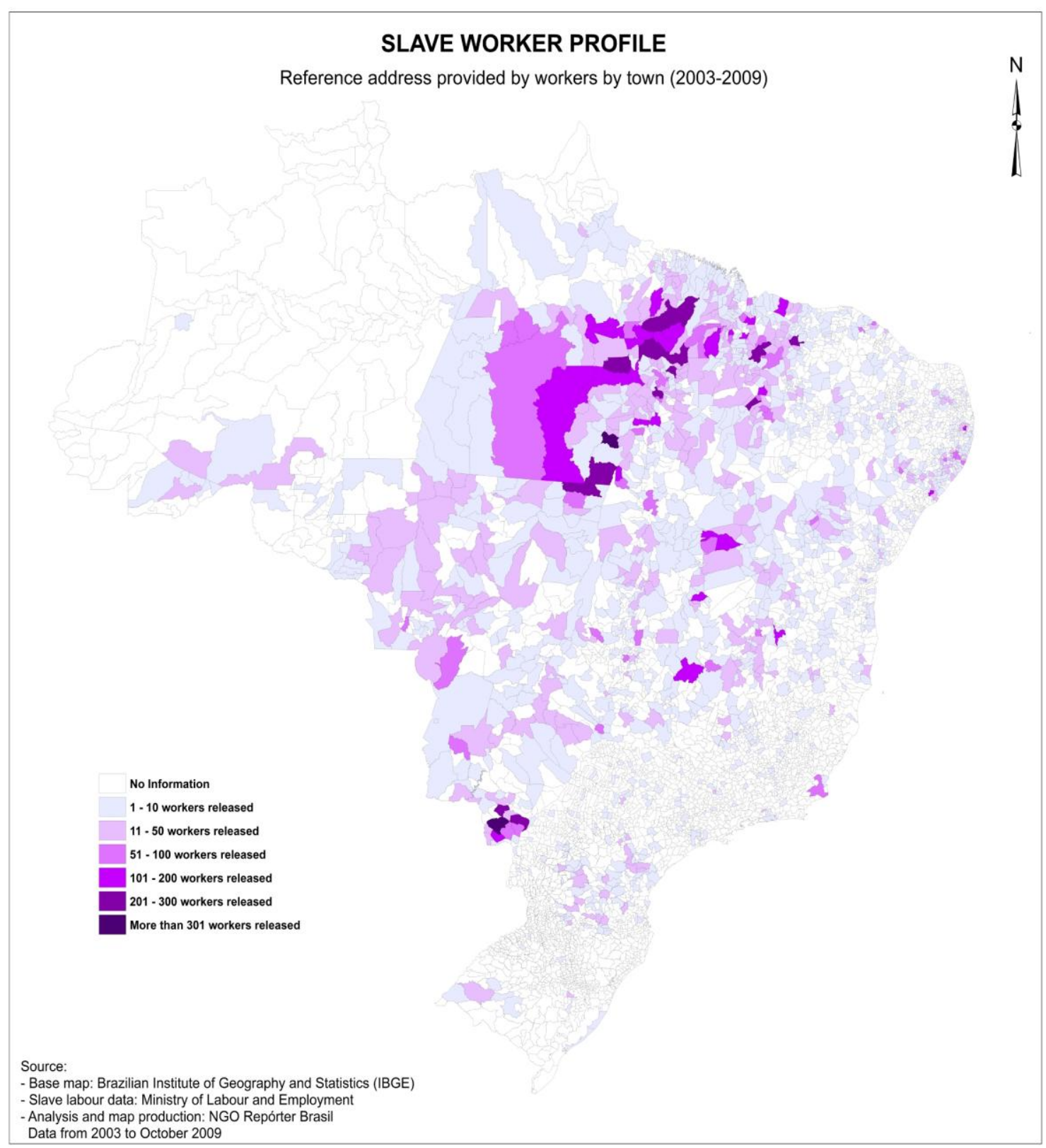




\section{Appendix 4: Human development index by town (2000)}

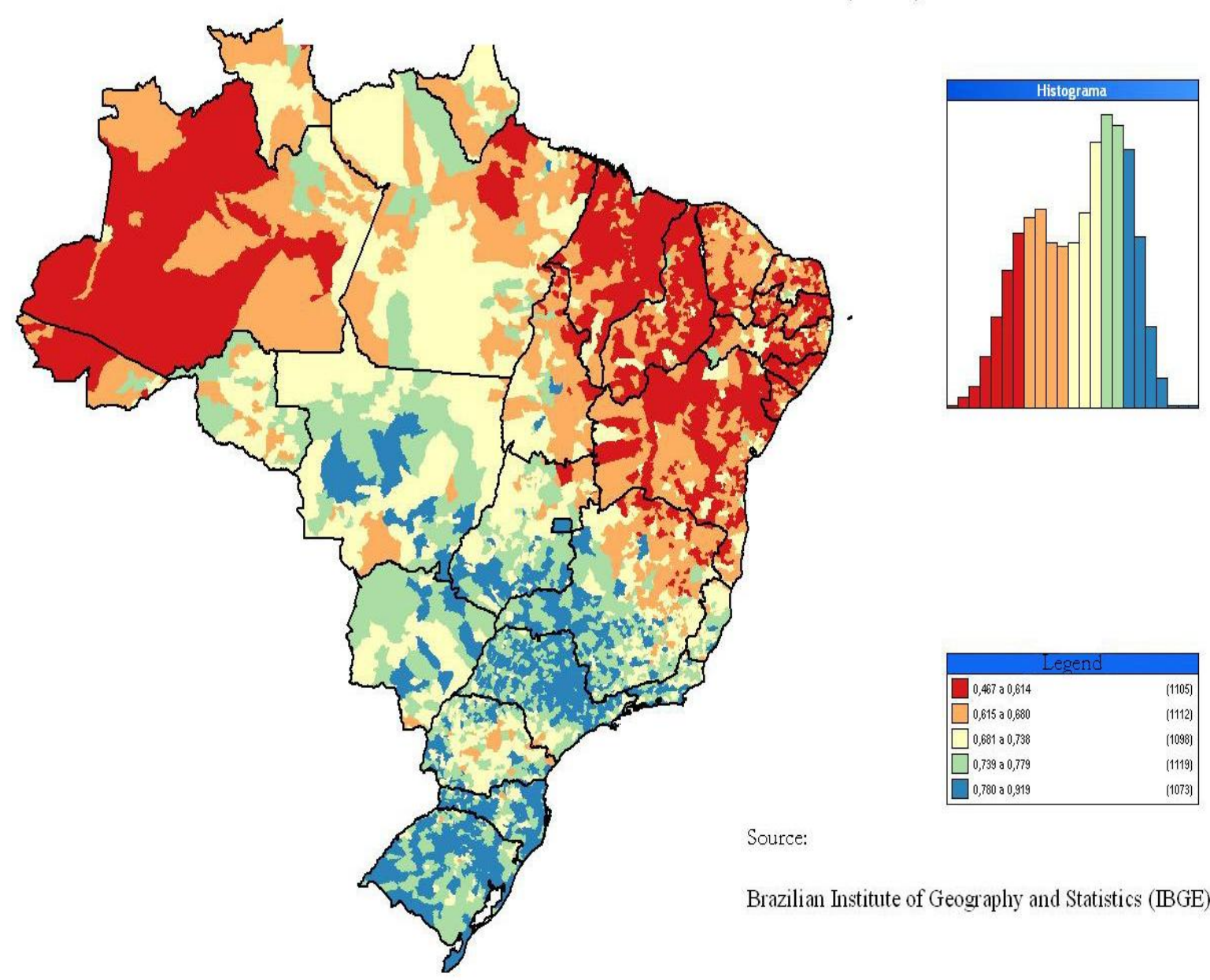


E

Chronic Poverty Research Centre

www.chronicpoverty.org

The Chronic Poverty

Research Centre

(CPRC) is an international

partnership of universities,

research institutes and NGOs,

with the central aim of creating

knowledge that contributes to

both the speed and quality of

poverty reduction, and a focus

on assisting those who are

trapped in poverty, particularly in sub-Saharan Africa and South Asia.

\title{
Partners:
}

Bangladesh Institute of

Development Studies (BIDS),

Bangladesh

Development Initiatives, UK

Development Research and Training, Uganda

Economic Policy Research Center, Uganda

HelpAge International, UK

Indian Institute of Public

Administration, India

IED Afrique, Senegal

Institute of Development

Studies, UK

Overseas Development Institute, UK

Programme for Land and Agrarian Studies, South Africa

University of Legon, Ghana

University of Manchester, UK

University of Sussex, UK

\section{Contact:}

cprc@manchester.ac.uk
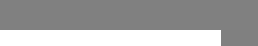

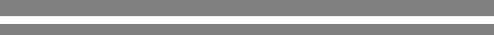

(n)

,

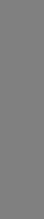

\author{
$x_{10}$
}

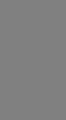

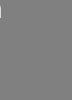

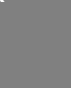

